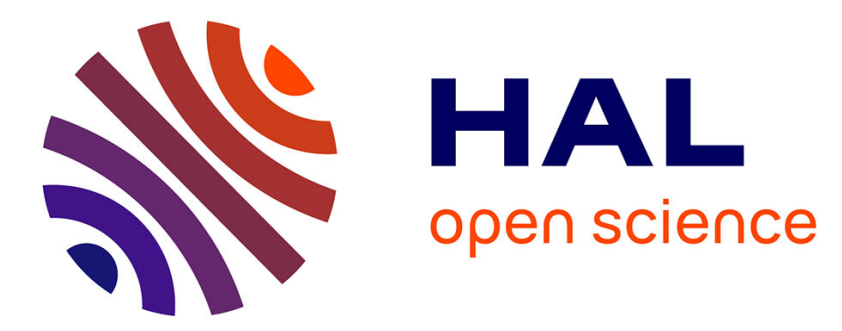

\title{
Price adjustment at multiproduct retailers
}

Daniel Levy, Shantanu Dutta, Mark Bergen, Robert Venable

\section{To cite this version:}

Daniel Levy, Shantanu Dutta, Mark Bergen, Robert Venable. Price adjustment at multiproduct retailers. Managerial and Decision Economics, 1998, 19 (2), pp.81-120. 10.1002/(SICI)10991468(199803)19:23.0.CO;2-W . hal-02385586

\section{HAL Id: hal-02385586 https://hal.science/hal-02385586}

Submitted on 28 Nov 2019

HAL is a multi-disciplinary open access archive for the deposit and dissemination of scientific research documents, whether they are published or not. The documents may come from teaching and research institutions in France or abroad, or from public or private research centers.
L'archive ouverte pluridisciplinaire HAL, est destinée au dépôt et à la diffusion de documents scientifiques de niveau recherche, publiés ou non, émanant des établissements d'enseignement et de recherche français ou étrangers, des laboratoires publics ou privés. 


\title{
Price Adjustment at Multiproduct Retailers
}

\author{
Daniel Levy \\ Department of Economics \\ Emory University \\ Atlanta GA 30322 \\ (404) 727-2941 \\ econdl@emory.edu \\ ShantanuDutta \\ Department of Marketing \\ School of Business Administration \\ University of Southern California \\ Los Angeles, CA 90089-1421 \\ (213) $740-5038$ \\ sdutta@sba.usc.edu \\ Mark Bergen \\ Dept. of Logistics and Marketing Mgmt \\ University of Minnesota \\ Minneapolis, MN 55455 \\ (612) 624-1821 \\ mbergen@csom.umn.edu \\ Robert Venable \\ Robert W. Baird \& Co. \\ bvenable@,rwbaird.com
}

Last Revision: December 30, 1997

JEL Codes: E31, E12, E50, G13, G14, L11, L15, L16, M21, M31, Q11, Q13

Key Words: Cost of Price Adjustment, Price Adjustment Process, Menu Cost, Posted Prices, Multiproduct Retailer, Price Rigidity, Sticky Prices, Frequency of Price Changes, Time Dependent Pricing, Retail Supermarket and Drugstore Chains 


\begin{abstract}
We empirically study the price adjustment process at multiproduct retail stores. We use a unique store level data set for five large supermarket and one drugstore chains in the U.S., to document the exact process required to change prices. Our data set allows us to study this process in great detail, describing the exact procedure, stages, and steps undertaken during the price change process. We also discuss various aspects of the microeconomic environment in which the price adjustment decisions are made, factors affecting the price adjustment decisions, and firm-level implications of price adjustment decisions. Specifically, we examine the effects of the complexity of the price change process on the stores' pricing strategy. We also study how the steps involved in the price change process, combined with the laws governing the retail price setting and adjustment, along with the competitive market structure of the retail grocery industry, influence the frequency of price changes. We also examine how the mistakes that occur in the price change process influence the actions taken by these multiproduct retailers. In particular, we study how these mistakes can make the stores vulnerable to civil law suits and penalties, and also damage their reputation. We also show how the mistakes can lead to stockouts or unwanted inventory accumulations. Finally, we discuss how retail stores try to minimize these negative effects of the price change mistakes.
\end{abstract}


"It is unfortunate that so little attention has been given to characterizing the circumstances that give rise to high and low levels of nominal price inertia. Progress in this dimension calls for more detailed empirical work and for increased understanding of the manner in which corporations actually arrive at pricing decisions."

Andrew Caplin

"Perhaps in no area of economic inquiry is there so wide a gap between theoretical and empirical work as in the field which has long been considered the core of economic analysis - the formation of prices."

NBER Committee on Price Determination

\section{INTRODUCTION}

The phenomenon of price adjustment is central in economics for several reasons. First, at the microeconomic level, since price adjustment is considered the main market clearing mechanism, whether prices adjust or not can have important implications for the efficiency of resulting allocations. Therefore, having a better understanding of the price change process can provide insights on issues like how rigid are prices of individual products, how fast are costs passed-through onto prices, how long it takes prices to adjust to changes in market conditions such as changes in supply and demand, etc. Second, at the managerial level of an individual business, pricing and price adjustment play a critical role as it determines the bottom line-profitability. For example, questions such as, how to adjust prices of individual products in response to temporary cost increases, how to adjust prices to competitors' price changes, how to adjust prices of sale and non-sale items, how frequently to change prices, etc., are all questions pricing managers and retail sellers face on a daily basis. Third, there are variety of markets (e.g., different types of auction markets, nonauction markets such as markets with posted prices, etc.) and understanding the specific characteristics of these institutions may help us better understand and predict the outcomes observed at these markets.

Given the importance of the price adjustment mechanism, it is not surprising that the issue has received considerable theoretical as well as empirical attention. At the theoretical level, the development of Walrasian paradigm where a continuous market clearing is achieved by an auctioneer has been studied rigorously. The insights gained from studying price adjustment at these auction markets are particularly relevant for our understanding of actual auction markets such as markets for most financial assets, and some agricultural crops and commodities such as soy, coffee, frozen concentrate orange juice, sugar, cotton, lumber, rubber, and some primary metals. Some nonreproducible tangible assets like antiques and art works are also sold through arrangements that closely resemble auction markets (Okun, 1981). These markets, which are characterized by the absence of price tags, have been the focus of hundreds of empirical studies by economists.

Far less is known, however, on the price adjustment process at non-auction markets. This despite the fact that "... most products are sold with price tags set by the seller and through a process of shopping by the buyer" Okun (1981, p. 138). In particular, not much is known on the price adjustment process at multiproduct seller. As Lach and Tsiddon (1996a) emphasize, most of the existing theoretical literature on price adjustment focuses on this problem from a perspective of an individual price setter selling a single homogeneous product. ${ }^{1}$ In reality, however, most sellers sell many heterogeneous products which makes 
price change management a nontrivial task for the firms. For example, as shown below, large supermarket chains, which often carry and sell as many as 25,000 different products, every week change prices of about 4,000 products, i.e., prices of about 15 percent of the products they carry. Also, as reported by Levy, et al. (1997a), the supermarket chains of this type and size on an average week may be experiencing cost changes on as many as 1,000-1,500 different products they sell, which makes the management of cost-based price adjustment decision and implementation not easy. Therefore, the price adjustment process in these types of establishments is a far more difficult, complex, and involved operation than in stores selling a single product.

For the purpose of emphasizing the complexity of the actual price adjustment process at large multiproduct retail stores, perhaps it is useful to recall two important differences between the Walrasian auction markets and more traditional markets that rely on posted prices. First, in the Walrasian market, the price adjustment is accomplished by an auctioneer who is "calculating" the extent of market disequilibrium and adjusts the price accordingly. In contrast, in the more common retail product markets, the sellers post prices and customers shop by searching for the best price across sellers. Therefore, the price adjustment, when it occurs, is not instantenous as in the auction markets. ${ }^{2}$ Thus, in these markets, also known as “customer markets," sellers are not really "price takers," rather they are "price makers" (Okun, 1981). ${ }^{3}$

The second difference between the two types of markets is in the role costs of changing prices play in the price adjustment process. The traditional formulations of the Walrasian markets, as described, for example, in a recent survey of Walker (1996), usually do not consider these costs of adjustment, which could include the cost of employing the auctioneer, the cost of calculating the extent of excess demand or excess supply, the cost of calculating the required price adjustment, etc. In this sense, the adjustment to equilibrium price in Walrasian markets is a costless process. ${ }^{4}$ In contrast, in markets with posted prices where consumers search through a shopping process, price adjustment is necessarily costly. ${ }^{5}$ Therefore, these costs of price adjustment need to be taken into account when making price change decisions.

In this paper we contribute to the literature by empirically studying the entire price adjustment process in multiproduct retail stores. ${ }^{6}$ Specifically, we use a unique store level data set collected during the 1991-92 period for five large supermarket and one drugstore chains in the U.S., to document the process required to change prices. The data set allows us to study this process in great detail, describing the exact procedure, steps, and the time required for each stage of the price change process. We also discuss various aspects of the microeconomic environment in which the price adjustment decisions are made, factors affecting the price adjustment decisions, and firm-level implications of price adjustment decisions. Specifically, we show how the complexity of the price change process influences the stores' pricing strategy decisions. We also show that the steps involved in the price change process, combined with the laws governing the retail price setting and adjustment, influence the frequency of price changes. Finally, we show that the mistakes that occur in the price change process influence the actions taken by these multiproduct retailers. In particular, we 
describe how the mistakes made in the price change process can make these stores vulnerable to civil law suits and penalties, and also damage their reputation. We also discuss how these mistakes can lead to stockouts or unwanted inventory accumulations. Finally, we discuss how retail stores minimize these negative effects of price change mistakes by participating in scanning certification programs offering scan guarantee refunds, and possibly also by reducing the frequency of price increases.

This paper builds on recent papers of Levy, et al. (1997a, 1997b), in which they report measures of price change costs for five large US supermarket and one drugstore chains, respectively. ${ }^{7}$ In those papers they focus on measuring the aggregated costs of changing prices and their macroeconomic significance. Here we append their data set with additional micro-level data provided by the Electronic Shelf Label company and extend their analysis by considering more disaggregated version of their data set. Also, unlike those studies, here our main focus is (i) the price adjustment process itself, (ii) the microeconomic settings in which the price adjustment decisions are made, and (iii) causes and consequences of various steps and decisions made as part of the price adjustment process. Further, what distinguishes this paper from the existing literature is that we study the actual (physical) price change process by documenting the specific steps involved in the price change process. Our use of this type of micro-level data is in the spirit of both Blinder (1994), who suggests that evidence on economic theories which rely on variables which are not readily available, are best obtained through primary data collected at the level of the decision maker, and Williamson (1985), who suggests that if the study of economic organizations are to progress then it is essential to collect more firm specific information at the level where decisions are made. In our case, we have access to the people throughout the retail organization who are actually changing the prices, which makes our data especially appropriate for studying price adjustment process at these organizations. Further, our use of this type of store level data builds upon an emerging literature which have used more micro level data to look at issues related to price rigidity (e.g, Lach and Tsiddon, 1992, 1996a, 1996b; Eden, 1994; Kashyap 1995; Warner, 1995; Warner and Barsky, 1995). Also, our data include information from one supermarket chain that is subject to item pricing law, which enable us to empirically study the role of item pricing laws in the price adjustment process. An added benefit of the approach we use is that in the process we learn a great deal about how price changes are actually done.

A detailed understanding of the costs associated with all aspects of the price change process can be valuable for managers. A decision to change a price of a product, like any other economic decision, has costs and benefits. In the area of pricing strategy, managers have developed an extensive understanding of the benefits associated with adjusting prices to changing market conditions. For example, in the grocery industry, studies of price elasticities, promotion sensitivities, and consumer responsiveness to pricing activity are frequently undertaken by branded manufacturers, retailers, and private companies such as, IRI, Nielson, Spectra, and FMI. Similarly, in industrial markets many firms undertake conjoint or tradeoff analysis to assess the price sensitivity of their customers (Nagle and Holden, 1995).

Yet, the costs associated with price adjustment activities are not as well understood by managers. 
This is in contrast to most other marketing decisions where the costs associated with many activities are much better understood. For example, the costs of major advertising campaign or the costs of hiring public relations firm are usually clear to the managers making these expenditure decisions. As another example, the costs of product line extension or new product line development are usually considered and understood by managers when making these decisions. By understanding the true costs associated with using pricing as a strategic tool, managers will be able to better understand when this tool is most appropriate and when it is less effective for achieving their goals.

The paper is organized as follows. In the next section we describe the data. In the third section we describe in detail the price tag and price sign change process in a representative store. In the fourth section we discuss the implications of the price change process for the retail sellers. The paper ends with a conclusion.

\section{THE DATA}

The data come from a company that sells electronic shelf label systems. These systems enable retailers to display the price on a shelf electronically from a central personal computer (where price changes are actually done) via a wireless communication system. The system consists of a personal computer based system controller, wireless communication network, electronic shelf labels and rails, and a fully integrated laser printer. Obtaining information from the in-store item and price data base, the system broadcasts this information to the shelf labels through a controller at each gondola. The laser printer produces paper shelf labels and signs. The system also maintains a continuous surveillance of the electronic labels to ensure that they are present and displaying the correct information. In addition, this label polling process also creates data on the physical location of the label within the store. Given the speed and accuracy of the electronic shelf label systems in changing and managing the shelf prices, they can be used by the retail supermarket and drugstore chains to greatly reduce the complexity and the lead times currently associated with changing shelf prices.

In order to sell the product, the company needed to validate what the existing processes of changing price tags and price signs were in the supermarket and drugstore chains. This company received a permission from each of the six chains to go to representative stores and record the exact steps involved in the price change process. A researcher worked with the people involved in the process of changing prices on the store floor where the shelf price tags are physically changed, and undertook detailed time (with a stopwatch) and motion recordings to measure the frequency of various steps undertaken in the price change process along with the required labor time. ${ }^{8}$ The studies were conducted during the years 1991-1992. ${ }^{9}$

These studies considered the entire price change and its implementation process in each chain. For this, detailed workflow schematics of each task in the price change process was developed. Observations of the process were conducted in multiple stores of the chains (at least two representative stores for each chain) to verify its accuracy. Information received from chains' pricing systems, in-store observations, and in-store counts and measurements, were used to determine the volume of work performed in each step 
of the task, the weekly frequency of each step performed, and the amount of time required to perform one unit of the work. After computing the total hours per task, this information was reconciled with the known total hours spent each week. This allowed for task level comparisons for the existing and test process.

Table 1a displays some general information about the supermarket and drugstore chains we study, the number of stores each chain operates, their pricing strategy, and information about the frequency of weekly price changes the stores undertake. The supermarket chains involved in this study are all large, multiple-store supermarket chains in the U.S. These chains are similar in terms of the variety, type, selection, and quantity of the products they carry. ${ }^{10}$ As the table indicates, the chains in our sample operate from under 100 stores to more than 1,000 stores across the U.S. Supermarket chains of this type make up more than $\$ 310$ billion in total annual sales, which is over $86 \%$ of total supermarket chain sales in 1992 (See Supermarket Business, 1993). As of 1995 there were 28,381 chain drugstores in the U.S. with total annual sales of $\$ 65.1$ billion. ${ }^{11}$ This comprises about 80 percent of the total, chain and independent drugstore sales (combined) of $\$ 81.4$ billion. ${ }^{12}$ Thus, the supermarket and drugstore chains combined constitute about $\$ 400$ billion in annual sales, or about 20 percent of the total retail sales. So the chains in our sample are representative of a major class of the retail grocery and drugstore trade. Since retail sales account for about 9.3 percent of the GDP, the price change process we document, directly applies to about 2 percent of GDP, which seem substantial.

Within the stores of Chain A, which is the chain we use in this paper as an example to illustrate variety of price change issues, the distribution of product shares, product movements, and weekly price changes across different departments are reported in Table 1b. According to the table, the General Merchandise/Health and Beauty Aid department has almost half of the items in the store but represents only 4 percent of the store's total movement. The Grocery, Frozen Food, and Dairy departments combined have 40 percent of the items in the store and account for 76 percent of the movement. In addition, Frozen Food and Dairy product departments have more than their proportional share of the average week's price changes.

\section{THE PRICE CHANGE PROCESS}

The price change process consists of at least eight different stages including (a) collecting competitive information, (b) managerial decision at the corporate headquarters to change a price, (c) price change preparation, (d) actual physical price change, (e) price change verification, (f) in-store resolution of the price mistakes, (g) zone and corporate resolution of price mistakes, and (h) scan guarantee refund. Additional stages are added to adjust the prices of direct-store-delivery products or to adjust the prices under the item pricing law. In this section we discuss each of these stages in detail.

Figure 1 displays a work flow overview of the price change process at Chain A and Figures 2-11 go into more detail of each step involved in this process. ${ }^{13}$ Each one of these figures is accompanied by a table which summarizes the amount of weekly time spent on each step described in the preceding figure. In these tables (Tables 2-11), the step numbers correspond to the numbers used in identifying them in the 
figures. For example, according to Figure 2, Step 5 involves "Finding Tags and Signs in Mail Box." From Table 2, we see that this step requires 72 seconds of labor. The following two columns in the table report the frequency at which Step 5 is executed each week (16 times), and the total amount of time spent on the task during the week (1,152 seconds). The last column of the table reports the share of the total weekly time spent on each step. ${ }^{14}$

Standard shelf price tag changes are characterized by the steps outlined on the left hand side of Figure 1: the price tag change preparation, price tag change, and price tag change verification boxes. These standard price changes make up the majority of price changes in these chains. For example, in a typical week stores at Chain A report 4,278 standard price changes (the sum of lines 1a, 1b, and 1c in the first column of Table 2). Some product prices also require additional price signs to be placed at different locations in the store, such as on an end of aisle display or on a sign near the shelf. These are usually related to the product being on display, promotion, feature advertising, or in-store sale. These price sign changes are outlined on the right hand side of Figure 1: the price sign change preparation, price sign changes, and price sign change verification boxes. Below we discuss and provide details of the specific steps and tasks performed at each stage.

\section{The Process of Collecting Competitive Information}

Before the price change process begins, which in the supermarket chains of the type and size studied here is done on a weekly basis, some information needs to be collected. In order to make a price change decision, price managers at corporate headquarters need to look at variety of competitive information. The process of collecting this competitive information is very involved. ${ }^{15}$ In the retail industry we study, people are sent on a weekly basis to competitors' stores to gather and record (usually by hand) their price and in-store sale and promotion information. ${ }^{16}$ For example, according to Jack Koegel, the President of Twin Value Foods chain, collecting competitors price information is not easy: "It takes time, and you've got to be accurate. Sometimes we are escorted to the door." (Progressive Grocer, October 1992, p. 52). Supermarket chains' marketing strategy is often based on "compare and save" image which can be promoted by promising lower prices than their competitors. To make such a promise credible, some chains actually display competitors price alongside theirs. For example, a Twin Valu Foods store of Canton, Ohio, routinely displays some 2,000 price-comparison signs along with the date their competitors' price was noted. To employ such a marketing strategy, the retail stores need to collect competitors' price information in an accurate and timely fashion.

This information must be coded, processed, and analyzed to be useful for price change decisions. This creates additional lags in the information flow, since it takes a few days to collect the information and get it in a usable form for the thousands of products sold in these retail stores. The costs of these information collection activities are large enough that many businesses are emerging in response to these costs, such as companies which have created electronic hand held systems to mechanize the process, ${ }^{17}$ and companies that are acting as a clearing house for grocers by offering a service where stores can post their 
prices and the other stores can download this price information by computer to save these collection and processing costs.

\section{Price Change Decisions at the Corporate Headquarters}

According to the Electronic Shelf Label company executives, once the relevant information has been collected, the price change process begins with a decision to change price at the corporate headquarters in a weekly meeting where the manager in charge of setting prices looks at a variety of information including: (a) any manufacturer wholesale price changes, promotions, and other related information, (b) latest store information on the product, which may include last week's sales, prices, and promotions, and (c) competitors' prices and promotions. Based on these information and on discussions with other managers, the price setting manager decides whether to change prices, and if so, by how much.

In an average chain there is at least one executive of merchandising, who devotes most of his/her time to pricing decisions. In addition, there are up to three senior managers who would deal with pricing and to whom category managers report. There are also 10-12 category managers who are responsible for setting prices on all the products within their category. Additional 2-4 people spend full time handling the implementation of price changes across retail outlets, coordinating the printing and delivery of price tags, and handling pricing problems in the system. Another 5-7 workers gather data on competitors' prices and analyse both, the store's own scanner data and competitors' data to put them in a form useable by managers making pricing decisions. Thus, in total there are about 21-27 people working at the corporate headquarters on price change decisions.

Although much of the pricing authority at most supermarket and drugstore chains is centralized, there may be some limited price variation at certain regions where the chains operate. For example, some stores will have "pricing zones" in which they cut prices more than their normal chain-wide price reductions (such as an additional 10 percent price cut) because the stores are located in especially competitive markets. A zone is a geographical grouping of several stores. For example, a large supermarket chain like Kroger may have 6-7 price zones in the metro Atlanta area. What this means is that the stores located in a particular zone have the same pricing strategies and policies. These will vary from zone to zone depending on competitive factors (e.g., amount of competition, pricing strategy of competitors, etc.), demographics, etc.

\section{Point-of-Sale Scanner Database Update}

Once a price change decision is made, its implementation in the supermarket computer systems such as point-of-sale (POS) scanner cash registers begins at the level of supermarket chain. The process works as follows. Suppose that a category manager of a chain decides to change the price of a product. These price changes are then entered into a centralized computer system at the chain headquarters. ${ }^{18}$ Once all price changes have been entered into the system, they are downloaded to all stores via a land-line or satellite transmission. These price data are deposited in the POS system. The scan coordinator, the person responsible for computer file maintenance, then activates these batches of hundreds of price changes all at 
once.

\section{Price Tag Change Preparation}

While changing the prices in the scanner data bases (POS systems) is a simple and quick process, the process of physically changing shelf (and, if required, item) price tags is more complex. Before a store begins to prepare for price tag change, the new price tags need to be printed. For this price tag orders must be recorded and processed at the chain, sent to the printer, recorded and processed at the printer, printed, packaged, and then finally delivered to each store. This process takes a significant amount of time, approximately 3 days at the chains in our sample. The price tag change preparation process is made up of 7 steps (Figure 2 and Table 2). The printed price tags are received over a 3-day period with effective dates ranging from Sunday through Wednesday (steps 1a through 1c). Once received (step 2), the price tags are sorted by department (step 3) and placed in the appropriate mailboxes to be picked up by the people putting the tags on the shelves (step 4). The price tags are then sorted by effective date (step 6). Finally, they are sorted and separated by aisle (step 7). Mistakes in sorting require additional time to correct. According to Table 2, the time each of these steps takes ranges from 35 minutes for sorting by department or by aisle, to 2.54 minutes to sort by effective date. In total, a supermarket store on an average week spends 6.02 labor hours on price tag change preparation (21,682/3,600 in Table 2$)$ which comprises 4.63 percent of the total time spent by the store on all aspects of price changes we document in this paper.

\section{Price Tag Change}

The actual price tag change process (Figure 3 and Table 3 ) is more complicated, and is made up of more than 25 steps including sorting tags, locating items, matching codes, removing old tags, and installing new tags. The tag changes are done by aisle (step 8), where they are sorted by sub-commodity (step 10). Once in front of the sub-commodity, the item must be located (step 14), and then the tag item codes, quantity and size, and prices must be checked to be sure that they match (step 15-15b). If they match, the old tag is removed (step 16) and the new tag is installed (step 17). ${ }^{19}$ At that point the workers must check to see if the item is located in another location in the store as well (step 18) and if it is, this process must be repeated (steps 19-22). If any of these steps cannot be completed, for example the old tag of the item can't be located (steps $14 \mathrm{c}-14 \mathrm{~g}$ ), or the new item tag code does not match the old item tag code (steps $15 \mathrm{c}-15 \mathrm{~g}$ ), then additional steps must be added to make corrections. In Table 3, the number of tags, the frequency of changes per week, the seconds required per tag, and the total time spent for each of these tasks are reported. Notice that all of these steps are measured in seconds. For example, it takes an average of 51.4 seconds to find items that are in different aisles (step 14f in Figure 3 and Table 3), and 14.4 seconds to go to selected aisle (step 9 in Figure 3 and Table 3). Note also that each of these actions may be repeated as many as 4,278 times for standard price changes. In total, a supermarket store on an average week spends 39.58 labor hours on price tag changes $(142,492.8 / 3,600)$ which comprises 30.44 percent of the time spent by the store on the price change process. 


\section{Price Tag Change Process in a Store Facing Item Pricing Law}

The specific steps undertaken during the price change process at Chain $\mathrm{E}$, which is operating in a state with item pricing laws, are similar to those undertaken by the other chains. However, stores that are subject to item pricing laws have to undertake additional steps to obey this law. These steps are needed when changing prices of the items already on store shelves. These steps (listed in Table 3a), which are in addition to the regular steps undertaken to replace price tags on the shelves as described in Figure 3 and Table 3, include: (1) obtaining item price tags, (2) setting up work-stations, (3) locating the product, (4) removing an item from the shelf, (5) removing old price tag, (6) setting marking gun, (7) applying new price tag, and (8) returning the item back to the shelf. ${ }^{20}$ Additional steps are undertaken to clear jammed marking guns and then to reload them.

\section{Price Tag Change for Direct Store Delivery Products}

Direct Store Delivery (DSD) is a term that is used primarily in the retail food industry to differentiate this form of delivery from a food store's main warehouse supply channel. Most retail food stores use some kind of dedicated warehouse channel for most of their product replenishment. However, for a number of reasons, the retailers find it preferable to obtain some products directly from outside product suppliers who deliver directly to the store rather than via their normal warehouse channel. The products handled through DSD arrangements usually are high-volume, fast-moving, and/or perishable products. For example, Bakery products are almost always direct store delivered because their short shelf-life makes moving them through regular warehouse system inefficient. Milk and many dairy products such as cheese and yogurt are also frequently delivered via DSD. Snack foods and cookies are often fragile, requiring careful handling and also require a considerable amount of shelf merchandising effort. Soft drinks have high shelf velocity, and also national brands are produced by franchised bottlers whose exclusive distribution territories do not match always wholesale warehouse distribution zones. Specialty distributors of food and merchandise are often used to provide assortment extensions. Finally, some general merchandise, greeting cards, periodicals, and health and beauty aids require considerable detailing in the store and are often supplied by the manufacturers (Little, 1996).

The share of a retail store's volume that is supplied via DSD varies depending on the type of store and the retailer's circumstances. For example, if a supermarket chain is short on warehouse space, it can swing towards a greater reliance on DSD and do the reverse when warehouse space is abundant. According to Little (1996) most food stores obtain 25-30 percent of their volume via DSD, although according to other estimates, this share may reach 40 percent of the volume sold (Direct Store Delivery Work Group, et al., 1995). In the chains we study, about 10-30 percent of the products sold are handled through some form of DSD. ${ }^{21}$

DSD manufacturers undertake most of the tasks that the retail chain would normally provide, such as stocking the shelves, monitoring shelf inventories, and setting and changing prices. Most of the steps 
involved in changing the prices of these products are similar to those undertaken by supermarket chains as described earlier in this section. For example, DSD personnel must print and deliver price tags, find the correct aisles including sale and promotion locations, remove old price tags and replace them with new price tags, and then verify that the process has been done correctly. However, there are additional steps to be undertaken to change prices of DSD products. Theses steps include (1) exchanging information between the supermarket (or drugstore) chain's headquarters and the DSD suppliers, which may include statements, price lists, and promotion announcements from the suppliers' side, and item authorization and payment advices from the retailer, (2) driving to the store, and (3) parking, and setting up the price change process at each store. According to the studies of the Direct Store Delivery Work Group, et al. (1995) and Little (1996) — a pilot time and motion study involving numerous large DSD vendors and supermarket chains such as Coca Cola, Anheuser-Busch, Ralphs Grocery Co., Kroger, Frito-Lay, Nabisco Foods, Giant Food Inc., CVS, Super ${ }_{\mathrm{X}}$, K-Mart, American Greetings, Hanes DSD, Proctor and Gamble, etc.one of the biggest problem in price change process of DSD products is coordinating it with the price managers of the supermarket chains. ${ }^{22}$

\section{Price Tag Change Verification}

After making the price tag changes, the new prices are checked to see if the changes have been done correctly. This process, the price change verification, which is described in Figure 4 and its companion Table 4 , is made up of over 15 steps. The steps undertaken in this stage are similar to the steps undertaken in the price tag change stage. For example, an employee needs to go to the right aisle (step 57), identify item in the report (step 58), locate item on the shelf (step 59), locate the printed price tag (step 60), compare the prices (step 61), and check off on computer report (step 62). This process is repeated until all price changes are checked in all aisles (steps 63 and 64). Finding an incorrect price information during the price change verification process requires an immediate attention such as ordering the correct price tags (steps $60 \mathrm{~b}$ or $60 \mathrm{~d}$ ) or researching further to determine the source of the error as described in detail in Figures 5 and 6. After noting all the required price tag changes that are needed to make the prices correct in the store, the employee checks the scanners at the registers (step 66) to see if it is a store error, or a problem at the zone or corporate level (step 68). Again, the times for each of these tasks range from a few seconds to a couple of minutes, and there are many prices to be checked in stores for these chains. For example, according to Table 4, steps 58 and 59 ("Read Item from Report" and "Find Item on Shelf") are undertaken 3,593 times each week and require 4.2 and 21.2 seconds each time, respectively. Similarly, steps 60 and 61 ("Locate Printed Tag" and "Price March?") are undertaken 4,006 times each week and require 2.1 and 5.3 seconds each time, respectively. In total, a supermarket store on an average week spends 39.65 labor hours on price tag change verification $(142,737 / 3,600$ in Table 4) which comprises 30.49 percent of the total time spent on price changes. Thus, verifying the accuracy of price tag changes seems to take as much time as the price tag changes themselves. 


\section{In-Store Resolution Process}

If during the price change verification stage a price mistake is found, an attempt is made to correct it immediately or after all price changes have been verified. See, for example, steps 60a-60d and 61a-61e in Figure 4. For this the store employees need to determine whether the mistake occurred at the store level (step 68-69) or perhaps at the zone or corporate level (68-No). The process of in-store resolution of price change mistakes is described in Figure 5 and Table 5. This stage consists of up to 25 different steps. As the figure indicates, there are many types of possible mistakes. For example, perhaps an item was not found (step 81) or, or may be it was found but UPC code did not match (step 82), or perhaps the prices did not match (step 81), or perhaps there are duplicate price tags, etc. In each case, the store scan coordinator, who is in charge of maintaining the price database of the store-level POS scanner, needs to look up on the POS system (steps 83,93 , or 100) to check the error and identify its possible origin.

The step undertaken next depends on the finding. For example, if the problem was that a product and its price tag were not found (step 80) but the price change was authorized (84-Yes), then the new price tag must be held till the product is received (step 85), and then once the products are placed on shelves, the price tags are installed (step 91). If the mistake is caused by a mismatch of the price tags (steps 81 or 92), then scan coordinator looks up the system (step 93) to determine which price tag is the correct one (step 94). The price tag with the incorrect information is discarded (step 96), or if necessary, a new price tag is prepared (step 95), which is installed on the shelf (step 97). If the problem is not resolved at the store level, then the scan coordinator communicates it to the zone and/or corporate scan coordinators via email (steps 103-106). The number of times each step is repeated in this stage depends on the frequency of the mistakes. For example, according to Table 5, the store scan coordinator looks up on system 149 times (the sum of the frequency of steps 83, 93, and 100 are repeated) each week. Out of these 149 inquiries, the coordinator ends up installing 87 new price tags (the sum of the frequency of steps 91, 97, and 102 are repeated) each week. In total, a supermarket store on an average week spends 7.27 labor hours on the instore resolution of price mistakes $(26,181.8 / 3,600$ in Table 5) comprising 5.59 percent of the total time spent on the price change process.

\section{Zone and Corporate Resolution Process}

Figure 6 and its companion Table 6 describe the process of price mistake problem solving at the zone and chain level of the supermarket. If the store scan coordinator is unable to resolve the problem at the store level because the problem has originated somewhere else, then the problem is reported via email to higher authority: the zone scan coordinator (step 103). The zone scan coordinator considers the problems reported from all stores included in the zone (step 107) and attempts to identify the origin of the price mistake (step 108). If it is determined that the mistake has occurred at the store level, the zone scan coordinator informs the store scan coordinator (step 109) who finally resolves the problem (step 110). Otherwise, the information is communicated via email to the price integrity department at corporate headquarters (step 111) where an attempt is made to determine whether the mistake occurred at the zone level or above (step 
113). ${ }^{23}$ If it is determined that the mistake occurred at the zone level, zone scan coordinators are informed about this (step 118) who communicate this information further to store scan coordinators (step 119) who resolve the problem (step 120). If, however, the problem has occurred at higher level (for example, at corporate headquarters), then the issue is researched further (step 114) followed with a set of steps necessary to resolve the problem at the store level (steps 115-122). In total, a supermarket store on an average week spends 0.23 labor hours on the zone and corporate resolution process of price mistakes (820.5/3,600 in Table 5) which comprises only 0.17 percent of the total time spent by the store on the entire price change process.

\section{Promotional Price Sign Changes}

Additional steps are required if the price change also requires a sign change (Figures 7-10 and Tables 7-10). ${ }^{24}$ In general, the actual steps involved in the process of sign change preparation (Figure 7 and Table 7) and in the sign change process (Figure 8 and Table 8 for hand-made signs and Figure 9 and Table 9 for pre-printed signs) are similar to the steps undertaken during the price tag change process. The main differences are that (i) the time required for each of the steps in the sign change process are longer because the signs usually are in less standard locations in comparison to shelf price labels which are usually inserted in rails attached to the shelves, (ii) the positioning and displaying the signs may involve some technical obstacles that need to be overcomed because they often come in nonstandard sizes, or because they often are hand made, and (iii) there are many fewer sign changes than standard shelf price tag changes, only 360 sign changes per week in supermarket Chain A (Table 7, line 23).

\section{Price Sign Change Preparation}

The sign change preparation process is made up of 7 steps (Figure 7 and Table 7). First, the per-printed signs are received (step 23). Once received (step 24), they are sorted by department in the store (step 25) and placed in the appropriate mailboxes (step 4) to be picked up by the people putting the signs on the shelves (step 5). The signs are then sorted by effective date (step 6). Finally, they are sorted and separated by aisle (step 7). Mistakes in sorting by department or effective date require additional steps to correct (steps 5a, 6a, or 7a). According to Table 7, the time each of these steps takes ranges from 1.9 seconds for sorting by department, to 4.8 minutes to locate the signs (step 5a-No). In total, a supermarket store on an average week spends 0.40 labor hours on the sign change preparation process $(1,422.9 / 3,600$ in Table 5) which comprises only 0.30 percent of the total time spent by the store on the price change process.

\section{Hand-Made Price Sign Change Process}

Often, the signs promoting some products as “Manager's Special," “This Week's Special," “This Week's Advertised Feature," etc., are hand-made within the store. Figure 8 and Table 8 describe the steps undertaken when such a sign change or installation is required as a result of price change decision. The process begins by going to the end of aisles (steps 26-28), which is where these signs are usually 
displayed, and noting the displayed products and their prices. The employee then goes to the shelf where the product is located (steps 29-30) and compares whether the prices on the shelf price tag and on the endof-the-aisle sign match (step 31). All products for which prices do not match and thus new signs need to be prepared for, are entered into a list (step 31a). Using this list, the employee goes to the end-of-the-aisle displays of each of these products (step 33) and removes the old signs with the incorrect price (step 34). She then goes to sign preparation area (step 35), prepares a new sign with the correct price and discards the old sign (step 36), returns to the location where the new sign will be displayed (step 37), and installs it (step 38). Once all sign changes/installations are made (step 39) and work area is cleaned (step 40), the employee proceeds to pre-printed sign change process. In total, a supermarket store on an average week spends 20.88 hours on the hand-made price sign changes $(75,171.6 / 3,600)$ which comprises 16.06 percent of the time spent by the store on the price change process.

\section{Pre-Printed Price Sign Change Process}

The main difference between pre-printed signs and hand-made signs is that pre-printed signs are not made within each store. Instead, they are made at regional centers and delivered to the store. According to Figure 9, the store employees first go and collect old signs with expired effective dates and destroy them. Specifically, an employee goes to an aisle (step 42), locates the existing pre-printed sign (step 43), and

checks the effective data (step 44). ${ }^{25}$ The signs with expired effective dates are destroyed (step 45). Once all the expired signs are removed (step 46), the new signs the worker carries with him/her (from step 41) are installed by locating the products (step 47), making sure that the information on the price and sign match (step 48) and then installing the new sign (step 49). This process is repeated for all products in the aisle (step 50) and for all aisles in the store (step 51). Finally, the employee also checks that the prices of advertised products and other sale items in newspaper inserts and in-store ads match the prices on shelves (steps 52-53). In total, a supermarket store on an average week spends 9.00 labor hours on the preprinted price sign change process $(32,385.6 / 3,600)$ which comprises 6.92 percent of the total time spent by the store on the price change process.

\section{Price Sign Change Verification Process}

As in the case of standard shelf price tag changes, supermarkets' employees take the time to verify that sign changes have been done correctly. The sign change verification process is described in Figure 10 and its companion Table 10. The process followed here is similar to the price tag change verification process. Someone needs to go to to the shelves and to the end-of-the-aisle displays where advertised, promoted, and sale products are located (steps 118-121) and compare the products (step 121a) and their prices to the advertised price (step 124). If the products do not match (step 121c) or if the prices do not match (steps 124-125), then new signs need to be prepared and installed (steps 121d or 125-127). In total, a supermarket store on an average week spends 4.50 labor hours on price sign change verification $(16,194.0 / 3,600$ in Table 5) which comprises 3.46 percent of the total time spent by the store on the price 
change process.

\section{IMPLICATIONS OF THE PRICE CHANGE PROCESS FOR THE RETAILERS}

The complexity of the price change process, and the resources that go into it have important implications for the retail stores and their activities related to price changes. For example, it plays a role in the retailers' decision on its overall pricing and price adjustment strategy. It has also implications for the frequency at which price change mistakes occur and thus for the resulting legal outcomes such as lawsuits and penalties. In this section we discuss these and other related issues as follows. We begin with a discussion of the retail chains' choice of overall pricing strategy, and the relationship between the retail grocery industry market structure and the frequency of price changes. We then discuss item pricing laws and their effects on the retailers' price adjustment process. Next we discuss the mistakes in the price changes process and their implications in terms of legal liabilities and penalties, reputation damage, and inventory effects. The section ends with a discussion of the retailers' efforts to reduce these negative consequences of the price change mistakes.

\section{Pricing Strategy: Every-Day-Low-Price vs High-Low Pricing}

One of the key steps in a retailer's planning process of its corporate objectives is the decision on its pricing strategy. Typically, retailers choose one of the two strategies: every day low price (EDLP) or highlow (HL) price. ${ }^{26}$ Under the EDLP strategy, the retailer's prices are low for extended periods of time and it will offer less promotional sales or discounts. Under the HL pricing strategy, in contrast, the retailer's prices are higher, and it tends to offer more frequent discounts through periodic sales and promotions. ${ }^{27}$

Recent studies have found that the share of retailers using some form of EDLP has increased from about 4 percent to 14 percent since early 1980s. ${ }^{28}$ This trend in pricing strategy is consistent with the importance of the cost of price adjustment. ${ }^{29}$ In fact, the reason most often mentioned for the emergence of EDLP stores is that it provides retail stores a more stable income flow and that it reduces managerial costs of changing prices (Lee, 1994). The pricing strategy, therefore, will have an effect on the frequency of price changes. Indeed (Table 1a), Chains A and B, which follow the HL pricing strategy tend to have higher number of weekly price changes (4,278 and 4,316 respectively) than Chains $C$ and $D$, which follow the EDLP strategy (and have 3,846 and 3,223 price changes, respectively).

\section{Market Structure and Frequency of Price Changes}

The figures in Table 1a also suggest that the supermarket chains are changing their prices rather frequently. For example, in a typical week, Chains A-D change prices of about 13-17 percent of the products they carry. ${ }^{30}$ The main reason for this frequent price changes is the fierce competition found in the retail supermarket industry. There are many players in this market and no single chain dominates it. Indeed, according to Consumer Reports (1993), the price competition is very intense in the retail grocery industry, it has frequent price wars (Calatone, Droge, Litvack, and DiBenedetto, 1989), and this price 
competition seems to have escalated over the years (Progressive Grocer, 1992 and 1993). The margin for the retailer is small, between 1-3 percent, which is further indication of the intensity of competition in this industry (Montgomery, 1994). Thus, the traditional competitive market model with many players is a reasonably good approximation of the retail supermarket industry.

According to the marketing literature (see, for example, Nagle and Holden, 1995, or Blattberg and Neslin, 1989), the three main factors affecting managerial price change decisions are (i) competitive factors, (ii) consumers price sensitivity (as measured through various elasticity estimates), and (iii) costs. Although the importance of these factors for determining specific pricing decisions may vary across individual price setters, the general practice in this industry seems to be to rank their significance in the order listed above. Similarly, in industrial markets, Farley, et al. (1980) find that the competitive factors tend to dominate most price change considerations: "Since no producer can expect to maintain prices higher than competitors for similar products delivered under given conditions for any period of time, prices must be competitive and any differential advantage is usually quickly matched. Hence, prices and volumes of each product are under continuous review as conditions constantly shift in many end-use markets..." (p. 46). They find that pricing systems of most retailers operating in such competitive environments are "feedback" mechanisms, triggered by perceived changes in market conditions that may warrant price adjustment for a specific transaction. ${ }^{31}$ As mentioned above (see the section on price change decisions at the corporate headquarters), the process of collecting this competitive information may be very involved. According to Levy, et al. (1997a), an average supermarket chain employs between 5-7 workers who are sent on a weekly basis to competitors' stores to gather and record their sales and promotion data and analyse them. These information must then be coded, processed, and analyzed to be useful for price change decisions. Thus, according to this literature, a significant amount of resources are spent on competitive data collection and elasticity measurements.

Nevertheless, many of the retailers are aware of their costs of changing prices. For example, Levy, et al. (1997a) report that because of the cost of price adjustment, the supermarket chains in their sample are not implementing about 20-35 percent of the cost-based price adjustments since the existing costs of price adjustment make these price adjustments unprofitable. As another example, Levy, et al. (1997c) document less frequent retail price changes during the Thanksgiving and the Christmas holiday periods in comparison to the rest of the year and find that this is mainly because of the cost of changing prices. Specifically, they find that during these holiday periods the opportunity cost of using employee time to change prices rather than perform other tasks such as restocking shelves, handling customers questions and inquiries, running the cash registers, and cleaning, rises substantially, which dramatically increases the costs of changing prices. Thus, the price managers of the retail supermarket industry are aware of the significance of these price change costs. ${ }^{32}$

\section{The Item Pricing Law}

The price adjustment process described above needs to take into account the various existing state 
and Federal laws governing the price change process. Examples of such laws include unit pricing laws, shelf pricing laws, and item pricing laws. ${ }^{33}$ The item pricing law requires that a price tag be placed on each individual item, in addition to the standard price tag displayed on the shelf. In the 1970's, with the advent of electronic scanner systems which could read the Universal Product Codes (UPC) from individual grocery items, a wave of item pricing laws were considered and enacted, both nationally and at the state level, with some of them still in force in some states, such as Connecticut, New York, Michigan, Massachusetts, California, and Illinois. ${ }^{34}$

The specific requirements of item pricing laws vary across states and jurisdictions. For example, according to FTC (1996), the City of Philadelphia does not impose any general item pricing requirement. Instead, the Philadelphia law requires that the retail food stores and supermarkets use item pricing when the store has a three-to-one or greater ratio of overcharges to undercharges for three consecutive inspections. These stores must then item price until they pass four consecutive inspections (Philadelphia, PA, Code $\S 9-1702,1996)$. The State of Michigan requires item pricing in all types of retail stores (Mich. Comp. Laws Ann., Code $§ 445.353$, West 1996). The Item Pricing Law in Connecticut exempts any retailer from the requirement of the law if the retailer implements an electronic shelf label system, with the approval of the commissioner of consumer protection (Conn. Gen. Stat. Ann., Code $§ 21 a-79$, West 1996). ${ }^{35}$ The item pricing laws of Massachusetts and California require item pricing in supermarkets and food departments of other retail stores (Mass. Gen. Laws Ann., Ch. 94, §§ 184C and 184D, West 1996; and Cal. Civil Code, $\S 7100$, West 1996). ${ }^{36}$

The requirement of posting prices on every item imposes a direct transaction cost on the retailers because with item pricing law, if price of a product is changed, then the store needs to replace not only the shelf price label, but also the price labels on each individual item already on the shelf. Therefore, stores located in states with item pricing laws will change prices less frequently than the other stores, ceteris paribus. Indeed, according to the figures in Table 1a, Chains A-D change prices on 12.89 to 17.26 percent of their products each week. In contrast, Chain E changes prices of only 6.31 percent of its products each week on average.

Further, within chain E there are 400 products that are exempt from this law, and thereby face lower costs of price adjustment. These products are physically located in areas where it is relatively more difficult to change individual price stickers. For example, these departments have items such as those displayed on peg hooks. These also include product categories with heavy concentrations of variable weight items which include products from bakery, floral, meat, seafood, and produce departments. Finally, these products include some refrigerated and frozen products to which applying and changing individual price labels is difficult.

In Tables $1 \mathrm{c}$ and $1 \mathrm{~d}$ we report the frequency of price change activity by product category in Chain $\mathrm{E}$ for products subject to the item pricing law (Table 1c) and for the rest of the products (Table 1d). A comparison of price change activity between the products that are exempted from the item pricing law and 
the products that are subject to the law indicate that overall, Chain E changes prices of about 6.3 percent of its products on average. However, for the 400 products that are not subject to the item pricing law, the chain on average changes prices of 83 products, that is 21 percent of the products. Thus, the average price change activity in the exempt product category is $31 / 2$ times higher in comparison to the rest of the products.

Moreover, a comparison of these figures by departments suggests that this pattern holds for most of the individual product group categories with the exception of frozen food, where the frequency of weekly price change, 22 percent, is the same regardless of whether item pricing law applies or not. In the latter category a likely reason for their frequent price changes, even when the products are subject to the item pricing law, may be the fact that most of these products have an expiration date which necessitates more competitive pricing. This also explains the finding of rather frequent price changes, 30 percent, in the dairy category (Table 1c). The requirement of the item pricing law increases the frequency of dairy product price changes from 30 percent to 52 percent (Table 1d). Overall, it is clear that the item pricing law leads to higher cost of changing prices which in turn makes prices more rigid.

\section{Mistakes in Price Changes}

Despite the labor put into checking to make sure that the price changes are done correctly, there are still many price mistakes that are not caught until customers discover them throughout the week. The retail stores need to take the implications of these mistakes into account when setting price change policies and decisions. For example, the mistakes have a negative impact and impose costs on stores in terms of potential civil suits and damaged reputation. These mistakes could also lead to stockouts or unwanted inventory accumulations. Therefore these mistakes are a relevant dimension of the price change process employed by these chains. In this subsection we discuss the frequency of price mistakes, we discuss legal and reputation aspects of these price mistakes, and we describe the retail chains' efforts aimed at improving the price change accuracy.

\section{Frequency of Price Mistakes}

Mistakes in the price change process can occur often. So often, in fact, that they were featured by TV programs, including NBC's Dateline (April 1992, and December 12, 1995) and ABC's Prime Time Live (April 8, 1993), as well as national printed media, including Information Week ("The Price Is Wrong," September 14, 1992, p. 26), Money ("Don't Get Cheated by Supermarket Scanners," April 1993, p. 132), and The Washington Post (“At the Register, Getting Rung Up ... and Riled,” June 8, 1994, p. A1)..$^{37}$

It should be noted that while price mistakes may occur for variety of reasons, most of them seem to be a direct result of the fact that the stores must maintain shelf price tags and signs for thousands of items and make sure that the posted prices match the prices in the store POS scanner computer database. In addition, as reported in Table 1a above, the stores usually change prices on thousands of products each week. According to the price accuracy study of the FTC (1996), many price mistakes, which usually occur 
when the POS scanner databases are not updated on a timely fashion, are primarily caused by inattentiveness and carelessness, rather than willfulness, of the employees of the stores. ${ }^{38}$

\section{Legal Implications of Price Change Mistakes}

Important cost of price mistake is potential legal problem such as a law suit in the case of overcharging, which occurs when the scanner price is higher than the shelf, or the advertised price. ${ }^{39}$ According to the FTC (1996), Weights and Measures Officials, who in many states have the authority to check the accuracy of store prices, can impose fines for violations of the state weights and measures act. In addition, in many states, the Attorneys General may bring actions based on the state's consumer protection or business/professions act.

For example, in 1994, the California Attorney General along with the Riverside District and San Diego City Attorneys have assessed a large discount store chain $\$ 985,000.00$ in civil penalties and costs for alleged scanner overcharges. As another example, in 1995, a department store, a discount store, an automotive supply company, and a chain drug store in Wichita, KS, were assessed $\$ 75,000.00$ in civil penalties for alleged scanner overcharges. In addition to possible penalties, states may also impose mandatory self-inspection programs and monitoring and correcting procedures by assigning pricing managers, which can be very costly. Such an arrangement has recently been instituted by the Consumer Affairs Unit of the Department of Finance of the City of Seattle, WA. Thus, retailers that do not pay serious attention to their pricing accuracy face the risk of legal fines and government mandated actions to correct the mistakes. Moreover, if retailers cannot guarantee high level of scanner accuracy, consumer mistrust in scanner technology may increase, which can lead to calls for a return to item pricing laws (FTC, 1996).

\section{The Implications of Price Change Mistakes for Retailers' Reputation}

Frequent discrepancies between price tag and cash register impose costs on the retailer in the form of lost customer goodwill and the resulting damaged reputation for the chain. Chains put considerable effort and resources into building customer confidence that they offer low prices. Discrepancies that occur between the price at the shelf and the price at the checkout damage that confidence. These goodwill costs are similar to the customer market ideas discussed by Alchian (1969), Okun (1975, 1981), Carlton (1989), and Haddock and McChesney (1994), who suggest the importance of considering customer goodwill when setting prices of goods traded in "search" markets. For example, according to Okun's (1975) customer market story, customers are counting on the stability of the prices offered by present suppliers, and price variation may lead the existing customers to search for alternative suppliers. Alchian (1969) presents a similar idea by arguing that stable prices perform an important role in reducing the need for search by potential customers. [See also Gordon (1981).] This will be particularly true if the price changes (price increases) are perceived by customers as out of norm and unfair. Since the sellers want to avoid this, they have incentive to leave prices unchanged (at least in the short run) even if market (i.e., supply and demand) conditions do not justify this. Therefore, cost of changing price should also include the negative 
reaction of existing customers to these price changes.

We do not have a measure of these costs, but they can be substantial. For example, a result of this loss of goodwill may be that customers will shop competitors' stores more frequently, and if angry enough, may no longer buy from the supermarket at all. To give a sense of the importance of this issue for the chains in our study, consider a survey undertaken by Chain A of 500 of its loyal shoppers in a particular regional area. They estimated that the tendency to switch stores, the annoyance with price discrepancies, and the frequency of exposure to these discrepancies combined, could lead to a loss of up to 8 percent of the existing customers to other chains annually because of this loss of goodwill.

\section{The Implications of Price Change Mistakes for Store Inventory}

Inventory mistakes are made due to the wrong price being on the shelf. If the price is incorrectly too high, there is too much inventory in the warehouse leading to additional holding costs, and if the price is incorrectly too low, there are stockouts ${ }^{40}$ which can lead to a loss of consumer purchases and goodwill (see the next subsection). When the new price is mistakenly higher than intended, the chain may experience unplanned inventory accumulation. This can be costly since the space could be used for another item. ${ }^{41}$ The probability of these type of mistake occurrences are proportional to the frequency of price changes: the more frequently prices are changed, the more likely it is to have mistakes.

\section{Retailers' Actions Designed to Minimize the Negative Impact of Price Change Mistakes}

We now discuss the steps undertaken by multiproduct retailers to minimize the negative impact of price change mistakes. First we describe programs in which some of the retail stores participate, programs designed to improve the accuracy of the price change process. Next we discuss policies the retail stores follow to compensate their customers who discover the price mistakes. Finally, we discuss the effect of price change mistakes on the possible asymmetry in the retailers' price change activity.

\section{Participation in Programs Designed to Improve Price Change Accuracy}

According to FTC (1996), state weights and measures offices in 42 states and the District of Columbia currently have a price verification and inspection programs in place. In addition to these government inspection programs, the retail food industry has set up its own certification and inspection programs. For example, in 1991 the Pennsylvania Food Merchants Association (PFMA), representing food retailers throughout the state, set up the first industry inspection program — the "Scanning Certification Program." This is a voluntary program that provides recognition for stores that have established standards of accuracy in the administration of their pricing and scanning programs. To be certified under this program, stores must earn at least a 98 percent accuracy rate on a random sample of 200 items taken from throughout the store. Once a store has been certified, periodic inspections are made to assess continued compliance. Participating stores also agree that in the event of an overcharge, one item will be given free to the customer, up to a limit of $\$ 10.00$. There are additional program requirements for the size and content of shelf tags and training of store employees. Currently 232 Pennsylvania supermarkets are certified under 
this voluntary program. Since its inception, the PFMA certification program reports an increase in the overall pricing accuracy from 96.9 percent to 98.55 percent in 1995. The Consumer Affairs Unit of the City of Seattle reports a decrease in the overall pricing error rates from 6.7 percent in 1994 to 3.7 percent in 1996. The average percentage of overcharges has also dropped from 4 percent in 1994 to 2.5 percent in 1995, and 1.4 percent in 1996.

\section{Scan Guarantee Refund and Other Compensation Policies}

One form of compensating the customers for the inconvenience caused by the price mistakes is scan guarantee refund which is a promise to shoppers that they will be charged the correct price, or else they will pay the lower of the two prices. In some chains, they may offer one item for free in case of pricing mistake. ${ }^{42}$ This kind of scan guarantee refund is most common in the retail food industry where it seems to have been a result of an outgrowth of customer service improvements.

Figure 11 describes the process followed to correct the price mistakes found by customers. In Table 11 we report the time cashiers spend in this process. As Figure 11 shows, the customer must first tell the cashier that the tag and cash register prices do not match (step 130). ${ }^{43}$ Then the cashier must check to see if the tag price is indeed lower. If it is, the cashier must offer the lower price (step 131) and complete a price discrepancy form (step 133). Eventually, someone will have to change the price in the POS scanner database register or make the price tag corrections (step 134). These mistake costs also include scan guarantee refunds, which may come in the form of additional price reductions beyond those which were at error (step 132b in Figure 11), or additional items given away for free because of the mistake (step 132a in Figure 11).

\section{Asymmetric Effect of Price Change Mistakes on Price Change Activity}

Blinder (1994) has suggested a possibility of asymmetry in the effect of cost of price adjustment on price change activities. Specifically, the firms' managers surveyed by Blinder indicated that adjustment costs they face deter price increases more often than decreases. With the exception of mistake costs, our data do not point to asymmetry of this sort. For example, given the structure of the price change process, the cost of labor used, the cost of preparing and delivering price tags, and the cost of in-store managerial time are not likely to be higher for price increases than price decreases. The same applies to the cost of changing prices of the DSD products. The cost of managerial decisions made at the corporate headquarters could have asymmetric effect only to the extend that decisions about price increases are more involved, more complex, and/or more difficult to make than decisions about price decreases. In that case, the cost of managerial decision on price increase could be higher than on price decrease leading to asymmetric effect on price change activity.

One component of cost of price adjustment that may have an asymmetric effect is the mistake cost. As a result of these mistakes the stores incur loss of cashier labor time that results from the need to correct the mistakes and to resolve the problem. Because of the asymmetric behavior of customers, the cost of 
these losses will be low if these mistakes favor the customers, but they can be very high if the mistakes favor the store since the store may loose reputation and customers goodwill and may even face legal problems. Another dimension of mistake costs we explored in the paper is the possibility that the mistakes in pricing may cause stockouts and lower profits (if the price is lower than intended), or excess inventory holdings (if the price is higher than intended). Whether the effect is asymmetric or not, than will depend on the relative magnitude of these two costs. Overall, the asymmetric effects of the mistake cost component of the price adjustment costs may indeed deter price increases more often than price decreases.

\section{CONCLUSION}

In this paper we studied the price adjustment process in the retail food and drugstore chains. Using a unique store-level data set, which allows us to document the exact process and time required to change prices, we show that changing prices is a complex process in these establishments, requiring dozens of steps and a non-trivial amount of resources. We find that the steps undertaken to implement the price changes have implications for the retail stores. Specifically, we show how the complexity of the price change process influences the stores' pricing strategy (EDLP vs HL pricing). We also show that the steps involved in the price change process along with the laws governing the retail prices (for example, item pricing law) influence the frequency of price changes. In particular, the frequency of price changes is lower for stores which are subject to the item pricing laws. Finally, we find that the mistakes that occur in the price change process may influence the actions taken by these multiproduct retailers. Specifically, we show that the mistakes made in the price change process could make these stores vulnerable to civil penalties and also damage their reputation. These mistakes can also lead to stockout or unwanted inventory accumulation.

We find that stores try to minimize these negative effects by participating in scanning certification programs and offering scan guarantee refunds. ${ }^{44}$ Given that very little is known on the practical aspects of the actual price change process, this paper fills an important gap in the existing literature.

In order to enhance our understanding of the way markets function in general, and in order to better understand the price adjustment process in particular, it will be valuable to undertake similar studies for other type of establishments, retail formats, industries, and markets. We anticipate that the price change processes will be similar in other markets that rely on posted prices (such as department stores, hardware stores, etc.) because the steps involved in the price change process are likely to be similar. There are, however, a variety of industries for which the steps involved in changing prices would be different from those reported in our study. For example, business-to-business sales which often rely on a salesforce, will require changes in the list price sheets, changes in the instructions to the salesforce which may include education and discussion with the salespeople in the company, and so forth. These business-to-business prices also often have more complex pricing schemes including quantity discounts, bundling, and individually negotiated prices. As another example, the process of changing newsstand prices of magazines [Cecchetti, 1986] or the process of changing the prices of products sold through catalogs 
[Kashyap, 1995], are very likely to differ from the price change process we reported here. Finally, since several authors (e.g., Ball and Mankiw, 1994, and Kashyap, 1995) suggest the importance of the managerial time and effort spent on price change decisions, in the future it may be useful to study the corporate managerial decision process on pricing and price adjustments in more detail. 


\section{Acknowledgements}

Address all correspondence to the first author. We would like to express our thanks to three referees and to Paul Rubin, the editor in chief, for providing useful comments and suggestions. Some sections of this paper are taken from a working paper titled "The Magnitude of Menu Costs: Direct Evidence from Large US Supermarket Chains," which was presented at the January 1996 American Economic Association Meeting in San Francisco, CA, and at the July 1996 NBER Economic Fluctuations Program meeting in Cambridge, MA. We are indebted to Andrew Abel, Peter Aranson, Martin J. Bailey, Nathan Balke, George Benston, Olivier Blanchard, Robert Chirinko, Leif Danziger, Hashem Dezhbakhsh, Xavier Drèze, Brett Drey, John Driscoll (the discussant at the American Economic Association meeting), Robert Hall (the discussant at the NBER Economic Fluctuations program meeting), Anil Kashyap, John Leahy, David Lilien, Akshay Rao, Bob Ruekert, Jeff Sandgren, Eytan Sheshinski, E. Somanathan, Daniel Tsiddon, and other seminar participants at the American Economic Association meeting, NBER Economic Fluctuations Program meeting, the marketing and the macroeconomics workshops at the University of Chicago, and the economics workshops at Emory, Southern Methodist, and Texas A\&M Universities for providing valuable comments and suggestions. Michael Caldwell, Huijun Che, Xia Liu, and Georg Müller provided excellent research assistance. The second and third authors would like to thank the Graduate School of Business of the University of Chicago for funding. All authors contributed equally to the work: we rotate the order of coauthorship. The usual disclaimer applies. 


\section{Notes}

1. The studies by Sheshinski and Weiss (1992), Lach and Tsiddon (1996a, 1996b), and Levy, et al. (1997a, 1997b) are exceptions.

2. According to Davis and Holt (1996), in laboratory experimental settings posted offer markets converge to competitive equilibria more slowly (Ketcham, Smith, and Williams, 1984), and less completely (Plott, 1986, 1989) in comparison to double oral auction markets.

3. Spulber (1996) examines theoretically the question of how the market equilibrium with price setting firms differs from the frictionless Walrasian framework.

4. See Arrow's (1959) seminal paper.

5. For example, the physical process of changing prices involves printing new price tags, and replacing old price tags with new tags. Moreover, managers need to spend time thinking about whether and how to change price, when to change it and by how much, they need to collect competitors price information and assess their promotional activities and pricing strategies, etc. In addition, price change decisions need to be followed by changing the prices in newspaper ad templates, conveying new price information to buyers, issuing new coupons, etc. Also, mistakes can occur during the price change process which can lead to additional costs in terms of damaged reputation as well as legal costs. Finally, sellers and buyers often develop implicit contracts and invest in establishing clientele with a pledge of continuity, and these customer-supplier relations may be damaged by frequent price adjustments. From customers point of view, additional components of cost of price adjustment include the planning difficulties frequent price adjustments create for buyers', customers' distrust of the sellers if prices change too often, and higher search costs associated with periodic purchases if prices are changed too frequently. These costs of changing prices, which are a form of transaction costs, are important ingredient of customer markets, and they arise naturally in many product markets because shopping process leads to tilted short-run demand curves, making temporary price adjustments unprofitable. See Phelps and Winter (1970) for an analysis of optimal pricing of a firm facing such a cost, which they describe more generally as an "economic friction." See also Alchian (1970).

6. It should be noted that the theoretical literature of price determination does not always distinguish between the process of determining the price of a product, and the process of deciding whether to change or not the price of a product (i.e., the price adjustment process). Historically, the setting of prices in the strict sense of the term has not been considered an important part of the pricing problem (Heflebower, 1955). 
For example, according to Dunlop and Martin (1940, p. 80), "Consideration of prices for most items ... centers around changes from established levels. [However] A decision not to change a quoted price in some circumstances where the market situation has changed radically may be as significant a decision as one in which an important price change is made." In this paper our focus is on the price adjustment process.

7. In the macroeconomic literature cost of changing price is often called "menu cost." See, for example, Mankiw (1985).

8. Although the Electronic Shelf Label company had an incentive to overstate the complexity of the price change process in order to sell the electronic shelf label system, we believe that the price change process we document here is reasonably accurate for a number of reasons. First, the Electronic Shelf Label company employees measured and documented all price change activities jointly with the supermarket employees. Second, time and motion measurements of the type used for measuring the menu costs we report here are routinely done by supermarket chains in order to assess the efficiency of their price change processes. The supermarket managers compared their practices to the Electronic Shelf Label company reports and found them to be similar. Further, these reports were presented to upper management of these chains and were found to be accurate description of their price change processes.

9. These studies were designed to help the electronic shelf label system manufacturer and its potential customers (retail stores and chains) assess the overall efficiency improvements an electronic shelf label system would provide. While these retailers in general seem to agree that electronic shelf label systems may help them make the price change process more efficient in comparison to the existing paper based price change system, purchasing an electronic shelf label system involves an assessment of both, the costs as well as the benefits of the system. According to the Electronic Shelf Label company, the main items included in the costs side of these cost-benefit considerations are the following. First, the direct cost of an electronic shelf label system, $\$ 100,000-\$ 150,000$, is substantial. Second, retailers face capital constraints, and alternative investment strategies, such as opening new stores or expanding existing stores, may yield higher net present value: a payback period of 2 years or less seems to be the minimum necessary in the retail supermarket and drugstore industry. Third, there is a concern over evolving technology standards and technological obsolescence: retailers need to be confident that the system works and that the vendor will be in business at least for the next five years minimum. Fourth, the electronic shelf label system only works with 60-75 percent of the products supermarket and drugstore chains carry (it does not work well with frozen products or variable weight products). Finally, the software and hardware require maintenance as well as operators' training.

10. Supermarket chains we study are similar in size to the supermarket chains included in the samples of 
Chevalier (1995), who studies capital and market competition of the retail food industry, and Slade (1996a, 1996b) who models and estimates costs of adjustments using a dynamic optimization framework.

11. The source of these figures is "Positive Sign: Chain Drugstore Sales Came on Strong in 1995, National Association of Chain Drug Stores Reports," Drug Topics, January 8, 1996, Vol. 140, No. 1, p. 91.

12. The total revenue estimate of $\$ 81.4$ billion is an average of two estimates we were able to find: (i) $\$ 80.8$ billion reported in “Annual Drugstore Sales Nearly Double in Decade,” Drug Topics, June 13, 1994, Vol. 138, No. 11, p. 118; and (ii) $\$ 82.4$ billion estimate derived by Nielsen company from its Household Panel Survey as reported in “Latest Nielsen Data: Inside Today's Drugstore Shopper,” Drug Topics, June 13, 1994, Vol. 138, No. 11, 89-100.

13. Similar time and motion studies were undertaken for the other chains. Chain $\mathrm{A}$ is presented here as an example. The price change process followed in other supermarket and drugstore chains is similar to what we report here.

14. In these tables the figures are reported on a weekly basis since prices at the supermarket and drugstore chains we study, like in most large retail chains, are changed on a weekly basis.

15. Information gathering cost has been suggested by Ball and Mankiw (1994) and Meltzer (1995) as an important component of cost of price adjustment. According to Meltzer (p. 102), “... one of the principal costs of price adjustment is the cost of acquiring information relevant for a decision about how much to change price."

16. Collecting competitors' price information on a weekly basis is a standard practice in this industry. See, for example, the stories on supermarket chains featured in the "Competition" column of Progressive Grocer on a monthly basis.

17. For example, according to the June 2, 1997 issue of the MacWeek magazine (p. 25), one such handheld device, Videx Inc.'s LaserLite Pro Bar-Code Reader, can read as many as eight different bar-codes including UPC (universal product code) and EAN (European Article Numbering standard, European equivalent of UPC). The device, which features an internal clock for recording date and time of each scan, has a 27-button alphanumeric keypad which can be used to enter data by hand, or to correct errors in the bar-code scans. The information collected by this bar-code reader can be downloaded almost instantenously into a desktop computer through a serial connection or through a wireless infrared data transfer mechanism. 
18. In some cases there will be different prices for the same product depending on various competitive factors and cost structures of individual stores.

19. There is some variation in the efficiency of this price change process across product categories. For example, finding items with unusual names or items that are slow sellers takes longer. Changing prices in freezers and refrigerators takes longer because of the need to open doors, price tags may not stick, hands get cold, etc.

20. According to the Electronic Shelf Label company, over 88 percent of the total cost spent on price tags production by this chain each year per store, is spent on price tags placed on each individual item. In an item pricing environment, these costs are heavily skewed by the product turnover, since faster selling items are allocated more shelf space which results in the need to change prices of more items already on the shelves.

21. The call frequency of some types of DSD suppliers to some stores can be as low as once per two weeks or even per month, but most call frequencies are at least once a week. Soft drinks are typically delivered several times per week to even medium sized stores, and bakery products are delivered daily to the larger stores. Because of this high frequency and the large number of DSD suppliers, DSD overwhelms warehouse delivery in total number of deliveries per store. For example, according to Little (1996), a store belonging to a large supermarket chain in an average week will receive about 100 DSD deliveries, and a chain drugstore in an average week will receive about 55 DSD deliveries. Overall, Little (1996) estimates that nationally there are over 500 million DSD deliveries to food stores alone every year, with drugstores, variety stores, and mass merchandisers adding almost half that amount again.

22. These coordination problems, according to the study, lead to frequent pricing mistakes. The cost of these mistakes seem to be important enough to prompt the companies participating in this pilot study to try and find ways of reducing it. One suggestion, according to the report of the study, is for the vendor and the supermarket to share their price databases by standardizing their database formats, software packages, and information technologies (Direct Store Delivery Work Group, et al., 1995; Little, 1996).

23. A "price zone" is defined above in the subsection on price change decisions at the corporate headquarters.

24. This will occur when there is a promotion, end of aisle display, or some form of feature advertising such as "Manager's Special," "Today's Special," "This Week's Advertised Feature," "Compare and Save," 
etc.

25. The effective data may be marked in several formats. Examples include "Effective till January 5, 1992," "This Price is Guaranteed Until Monday," and "Sale Ends Sunday."

26. High-Low pricing strategy is sometimes know as "deal pricing" (Blattberg and Neslin, 1989).

27. The most common reason mentioned in the literature for the use of HL pricing strategy is that it allows the retailers to price discriminate (Jeuland and Narasimhan, 1985). Higher share of retail stores follow the HL pricing strategy perhaps reflecting customers preference towards periodic deep price discounts (Blattberg and Neslin, 1989). Other factors that affect the choice of pricing strategy include competitive factors, demographic factors, public image and perception, etc. Whatever choice the retailer makes is important since it determines retailer's success in achieving its objectives in terms of generating store traffic, moving excess inventories, enhancing the store's image, and creating a price image.

28. See, for example, Blattberg and Neslin (1989), Lattin and Ortmeyer (1991), Marketing News (April 13, 1992, p. 8), and Hoch, Drèze, and Purk (1994). One large department store that has recently switched from HL pricing strategy to the EDLP strategy is Montgomery Ward.

29. According to Lattin and Ortmeyer (1991), EDLP can also reduce advertising expenses. For example, Wal-Mart, EDLP leader, advertises in newspapers on a monthly basis, whereas many of their competitors do promotional advertising 52 weeks a year. Since promotional advertising usually involves prices decrease (sale) information, a switch to EDLP can save this component of the cost of price adjustment. The retail toy market giant, Toys "R" Us usually advertises its products through newspaper inserts on a weekly basis. However 100 percent of their merchandise comes prepriced from the manufacturers, and the store almost never changes them (with the exception of clearance items). Therefore, Toys "R" Us' ads are not really "sales" ads. Rather, the chain uses the ads only to inform consumers of its prices.

30. Note that according to Table 1a the chain drug store in our sample on an average week changes the prices of only about 7-8 percent of the products it carries. The large difference in the frequency of price change activity between these two retail formats may be due to differences in the target customers of the two retailers. Specifically, studies have shown that supermarket customers may be more price sensitive than drugstore customers (Quelch, 1981; and Bob Ruekert, in private conversations). Further, most people spend more money in supermarkets than in drugstores: the basket of products bought on an average trip to a drugstore is significantly smaller than what most of us buy during our weekly supermarket visit, and according to Nagle and Holden (1995), customers tend to be more price sensitive when total expenditures 
are higher, ceteris paribus. Another reason for this difference may be the different shopping patterns and buying cycles of customers frequenting these two types of retail formats. Customers at drugstores tend to buy much less frequently relative to supermarket customers who usually shop for the basic items at least on a weekly basis. Also, the purchases made at drugstores tend to be more random. Consistent with these arguments are these facts: (1) Most of the products in the drugstore have a longer shelf-life than in the supermarket, (2) inventory turnover is much slower in the drugstore, and (3) drugstores are not volume driven to the same extent as supermarkets. The lower frequency of price changes at chain drugstores is a major reason why chain drugstores have the lower menu cost per product and the lower menu cost to gross margin ratio relative to the supermarket chains. See Levy, et al. (1997b) for further discussion of this point. For studies of the frequency of price changes of individual products in an US supermarket of the type and size included in our data set, see Levy,et al. (1996), Dutta, et al. (1997), and Levy, et al. (1997c).

\section{See also March and Simon (1958).}

32. In informal interviews Levy, et al. (1997c) conducted among numerous supermarket chain managers, they have indicated their awareness of the significance of these price change costs, and expressed surprise that the university professors seem not to be aware of their importance.

33. Unit pricing laws usually require the prices of products in similar category be displayed per comparable units. For example, the prices of all cereals should be displayed not only per box, but also per oz. which makes price comparison across different brand, size, and packaging of cereals easier for customers. The shelf price law requires that a price tag be posted on the shelf. In some states this law also prohibits price change on the items already on the shelf. This means that if a store changes the price of a product, then the items already on the shelf must be sold at the original price, and only the new items of the same product brought out storage can be sold at the new price.

34. For example, the item pricing law in Connecticut requires that the grocers "shall mark or cause to be marked each consumer commodity which bears a Universal Product Code with its retail price (Public Act No. 75-391: An Act Concerning Pricing of Consumer Merchandise, in Public Acts of the State of Connecticut, 1975, Vol. 1, p. 390).

35. The Massachusetts Food Retailers Association is currently negotiating with the state to grant similar item pricing exemptions to the retailers that adopt the electronic shelf label systems.

36. The benefits of the item pricing law, according to its proponents, are increased consumer awareness of price, which can lead to more informed shopping behavior, and a better ability to notice price mistakes. 
37. For example, the Money magazine reports that in a study of 27 major supermarket chains in 23 states, on average one out of every 10 items had a price mistakes. A similar figure is reported by Goodstein (1994), who examines price accuracy at three large supermarket chains in California, and finds that on average 9 percent of the products have price mistakes. The frequent media reports of supermarket price mistakes has prompted the Federal Trade Commission (FTC) and the National Institute of Standards and Technology (NIST) along with several state level Attorney General's offices and Consumer Protection agencies from Florida, Massachusetts, Michigan, Missouri, Tennessee, Vermont, and Wisconsin, to undertake a detailed study of the accuracy of retail prices in randomly selected 294 stores representing food, auto, drug, toy, home improvement, discount, department, and miscellaneous chains, over a three year period from 1994 to 1996. In this study the Federal Trade Commission (1996) found a smaller average mistake rate, about 5 percent.

38. One may consider price change mistakes involving overcharging, in the context of models of misleading advertising. See, for example, Peltzman (1981) and Mathios and Plummer (1989).

39. According to Goodstein (1994), overcharging (i.e., the shelf price tag or the advertised price is lower than the scanned price), which averages $\$ 0.24$ per transaction, occurs in 3.6 percent of the regularly priced products, in 7.3 percent of the advertised products, and in 6.0 percent of the end-of-aisle-specials products on average. He also reports that undercharging (i.e., the shelf price tag or the advertised price is higher than the scanned price), which averages $\$ 0.83$ per transaction, occurs in 4.8 percent of the regularly priced products, in 1.8 percent of the advertised products, and in 3.6 percent of the end-of-aisle-specials products on average. In the FTC (1996) study, overchargings were found in 2.24 percent of the items checked, and underchargings were found in 2.58 percent of the items checked, on average.

40. According to the Electronic Shelf Label company, an average of 771 products are out-of-stock in a given week because of the price change activity at Chain A.

41. To give an idea of the magnitude of these costs, Müller (1995), using 25 percent of the retail price as an estimate of the inventory holding cost, reports that the annual cost of excess inventory holding in supermarket chains of the type and size we study, can be as high as $\$ 10,000$ per store for some product categories (e.g, analgesics).

42. For example, large signs in Kroger stores in Atlanta declare "Scan-Rite Guarantee: receipt higher than shelf tag—one of that item is yours FREE." 
43. We have no data on the frequency of complaints by customers when the price discrepancy they discover is in their favor. That is, when the price at the cash register (POS scanner computer database) is lower than the shelf price (step 129a-Yes).

44. While the findings we report in this paper may be interpreted as pointing toward inefficiencies and rigidities characterizing the price adjustment processes in market settings that rely on posted price tags and price signs to convey price information to potential buyers, this type of market organization has some important advantages, as Davis and Holt (1996) remind us. For example, the posted price market arrangement enables large multiproduct retailers reduce the need and the cost of monitoring sales clerks. The posted price systems with take-or-leave-it arrangements also reduce the transactions and negotiation costs. In addition, posting prices make it easier to advertise sale and promotion prices. 


\section{REFERENCES}

G. A. Akerlof and J. L. Yellen (1985). A Near-Rational Model of Business Cycle, with Wage and Price Inertia. Quarterly Journal of Economics, 100 supplement, 823-838.

A. A. Alchian (1969). Information Costs, Pricing, and Resource Unemployment. Western Economic Journal, 7, No. 2, June, 109-128.

K. J. Arrow (1959). Toward a Theory of Price Adjustment. In The Allocation of Economic Resources (edited by M. Abramovitz, et al.), Stanford, CA: Stanford University Press, pp. 41-51.

L. Ball and N. G. Mankiw (1994). A Sticky-Price Manifesto. Carnegie-Rochester Conference Series on Public Policy, December, 127-152.

M. Bergen, S. Dutta, and S. S. Shugan (1996). Branded Variants: A Retail Perspective. Journal of Marketing Research, 33, 9-19.

R. C. Blattberg and S. A. Neslin (1989). Sales Promotion: Concepts, Methods, and Strategies, Englewood Cliffs, NJ: Prentice Hall.

A. S. Blinder (1994). On Sticky Prices: Academic Theories Meet the Real World. In Monetary Policy (edited by N.G. Mankiw), National Bureau of Economic Research: University of Chicago Press, 117-150.

R. J. Calatone, C. Droge, D. Litvack, and C. A. DiBenedetto (1989). Flanking in a Price War. Interfaces, 19, March-April, 1-12.

A. Caplin and J. Leahy (1997). Aggregation and Optimization with State-Dependent Pricing. Econometrica, 65, No. 3, May, 601-625.

D. W. Carlton (1986). The Rigidity of Prices. American Economic Review, 76, Sept., 637-658.

D. W. Carlton (1989). The Theory and the Facts of How Markets Clear: Is Industrial Organization Valuable for Understanding Macroeconomics? In Handbook of Industrial Organization Vol. 1 (edited by R. Schmalensee and R. D. Willig, Amsterdam: North Holland, pp. 909-946.

D. W. Carlton and J. M. Perloff (1994). Modern Industrial Organization, New York: Harper Collins.

S. G. Cecchetti (1986). The Frequency of Price Adjustment: A Study of the Newsstand Prices of Magazines. Journal of Econometrics, 31, April, 255-274.

J. A. Chevalier (1995). Capital Structure and Product Market Competition: Empirical Evidence from Supermarket Industry. American Economic Review, 85, No. 3, 415-435.

Committee on Price Determination (1943). Cost Behavior and Price Policy: A Study Prepared by the Committee on Price Determination for the Conference on Price Research, New York: National Bureau of Economic Research.

L. Danziger (1987). Inflation, Fixed Cost of Price Adjustments, and Measurement of Relative Price Variability. American Economic Review, 77, No. 4, September, 704-713.

D. D. Davis and C. A. Holt (1996). Markets with Posted Prices: Recent Results from the Laboratory. Discussion Paper 270, University of Virginia, September.

Direct Store Delivery Work Group, et al. (1995). Direct Store Delivery: An Efficient Consumer Response Best Practices Report. Joint Industry Project on Efficient Consumer Response, Industry Relations Department, Grocery Manufacturers of America.

A. Dixit (1991). Analytic Approximation in Models of Hysteresis. Review of Economic Studies, 58, $141-152$.

J. T. Dunlop and E. M. Martin (1940). International Harvester Company. In Industrial Wage Rates, Labor Costs, and Price Policies(edited by D.V. Brown, et al.), Temporary National Economic Committee, Number 5.

S. Dutta, M. Bergen, and D. Levy (1997). Price Flexibility in Channels of Distribution: Evidence From Scanner Data. working paper, University of Southern California, University of Minnesota, and Emory University. 
B. Eden (1994). Time Rigidities in the Adjustment of Prices to Monetary Shocks: An Analysis of Micro Data. Discussion Paper No. 94.16, Bank of Israel, November.

J. U. Farley, J. M. Hulbert, and D. Weinstein (1980). Price Setting and Volume Planning by Two European Industrial Companies: A Study and Comparison of Decision Processes. Journal of Marketing, 44, 46-54.

Federal Trade Commission (1996). Price Check: A Report on the Accuracy of Checkout Scanners. A Report by the Staff of the Federal Trade Commission, Technology Services of the National Institute of Standards and Technology, the States of Florida, Michigan, Tennessee, Vermont, and Wisconsin, and the Commonwealth of Massachusetts, October 22.

M. Friedman and A. J. Schwartz (1963). A Monetary History of the United States, 1867-1960, Princeton, NJ: Princeton University Press.

R. C. Goodstein (1994). UPC Scanner Pricing Systems: Are They Accurate? Journal of Marketing, 58, April, 20-30.

R. J. Gordon (1981). Output Fluctuations and Gradual Price Adjustment. Journal of Economic Literature, 19, No. 2, June, 493-530.

D. D. Haddock and F. S. McChesney (1994). Why Do Firms Contrive Shortages? The Economics of Intentional Mispricing. Economic Inquiry, 32, No. 4, October, 562-81.

R. B. Heflebower (1955). Full Costs, Cost Changes, and Prices. In Business Concentration and Price Policy (edited by G. Stigler), A Conference of the Universities-National Bureau of Economic Research Committee for Economic Research, Princeton, NJ: Princeton University Press, 361-392.

S. J. Hoch, X. Drèze, and M. E. Purk (1994). EDLP, Hi-Lo, and Margin Arithmetic. Journal of Marketing, 58, October, 16-27.

A. Jeuland and C. Narasimhan (1985). Dealing-Temporary Price Cut-by Seller as a Buyer Discrimination Mechanism. Journal of Business, 58, No. 3, 295-308.

A. K. Kashyap (1995). Sticky Prices: New Evidence from Retail Catalogues. Quarterly Journal of Economics, 110, No. 1, February, 245-274.

V. Ketcham, V. L. Smith, and A. W. Williams (1984). A Comparison of Posted Offer and Double-Auction Pricing Institutions. Review of Economic Studies, 51, 595-614.

S. Lach and D. Tsiddon (1992). The Behavior of Prices and Inflation: An Empirical Analysis of Disaggregated Data. Journal of Political Economy, 100, No. 2, 349-389.

S. Lach and D. Tsiddon (1996a). Staggering and Synchronization in Price Setting: Evidence from Multiproduct Firms. American Economic Review, 86, No. 5, 1175-1196.

S. Lach and D. Tsiddon (1996b). Small Price Changes and Menu Costs. The Maurice Falk Institute for Economic Research in Israel, Discussion Paper No. 96.06, March.

J. M. Lattin and G. Ortmeyer (1991). A Theoretical Rationale for Everyday Low Pricing by Grocery Retailers. Working Paper, Graduate School of Business, Stanford University.

K. Lee (1994). Determinants of EDLP Store Patronage and Deal Usage. Unpublished Dissertation, Graduate School of Business, University of Chicago.

D. Levy, M. Bergen, S. Dutta, and R. Venable (1997a). The Magnitude of Menu Costs: Direct Evidence from Large U.S. Supermarket Chains. Quarterly Journal of Economics, 112, No. 3, August, 791-825.

D. Levy, M. Bergen, S. Dutta, and R. Venable (1997b). Menu Costs, Posted Prices, and Multiproduct Retailers. working paper, Emory University, University of Minnesota, and University of Southern California, August.

D. Levy, S. Dutta, and M. Bergen, (1996). Heterogeneity in Price Rigidity and Shock Persistence. working paper, Emory University, University of Southern California, and University of Minnesota.

D. Levy, G. Müller, S. Dutta, and M. Bergen, (1997c). Price Rigidity During Holiday Periods: The Role of Menu Costs. manuscript, presented at the January 1998 American Economic Association meeting in Chicago. 
Y. Lieberman and B. Zilberfarb (1985). Price Adjustment Strategy Under Conditions of High Inflation: An Empirical Examination. Journal of Economics and Business, Vol. 37, 253-265.

A. D. Little, Inc. (1996). Direct Store Delivery: Store Level Study. Reference 55643, April.

N. G. Mankiw (1985). Small Menu Costs and Large Business Cycles: A Macroeconomic Model of Monopoly. Quarterly Journal of Economics, 100, May, 529-539.

J. G. March and H. A. Simon (1958). Organizations, New York: John Wiley and Sons.

A. Mathios and M. Plummer (1989). The Regulation of Advertising by the Federal Trade Commission: Capital Market Effects. In Research in Law and Economics, Vol. 12 (edited by R. O. Zerbe), Greenwich, CT: JAI Press, pp. 77-93.

A. H. Meltzer (1995). Information, Sticky Prices, and Macroeconomic Foundations. Federal Reserve Bank of St. Louis Review, 77, No. 3, June, 101-118.

Money Magazine (1993). Don't get cheated by Supermarket Scanners. By V. O’Connell, 22, No. 4, April, 132-138.

A. L. Montgomery (1994). The Impact of Micro-Marketing on Pricing Strategies. Ph.D. Dissertation, Graduate School of Business, University of Chicago.

G. Müller (1995). The Optimal Inventory Cycle When Inventory Affects Demand. University of Chicago, Graduate School of Business Working Paper, April.

T. T. Nagle and R. K. Holden (1995). The Strategy and Tactics of Pricing, Englewood Cliffs: Prentice Hall.

A. M. Okun (1975). Inflation: Its Mechanics and Welfare Costs. Brookings Papers on Economic Activity, 2, 351-390.

A. M. Okun (1981). Prices and Quantities: A Macroeconomic Analysis, Washington, DC: The Brookings Institution.

M. Parkin (1986). The Output-Inflation Trade-off When Prices Are Costly to Change. Journal of Political Economy, 94, February, 200-224.

S. Peltzman (1981). The Effects of FTC Advertising Regulation. Journal of Law and Economics, 24, No. 3, December, 403-448.

E. S. Phelps and S. G. Winter, Jr. (1970). Optimal Price Policy under Atomistic Competition. In Microeconomic Foundations of Employment and Inflation Theory (edited by E. S. Phelps, et al.), New York, NY: W.W. Norton \& Company, Inc., 309-337.

C. R. Plot (1986). The Posted-Offer Trading Institution. Science, 232, 732-738.

C. R. Plot (1989). An Updated Review of Industrial Organization: Applications of Experimental Methods. In Handbook of Industrial Organization, Volume II (edited by R. Schmalensee and R. Willig), New York: North Holland.

J. A. Quelch (1981). Vaseline Petroleum Jelly Case Study. Chesebrough-Pond's Inc, Harvard Business School.

C. D. Romer and D. Romer (1989). Does Monetary Policy Matter? A New Test in the Spirit of Friedman and Schwartz. National Bureau of Economic Research Macroeconomics Annual , 4, 121-170.

E. Sheshinski and Y. Weiss (1977). Inflation and Costs of Price Adjustments. Review of Economic Studies, 44, 287-303.

E. Sheshinski and Y. Weiss (1992). Staggered and Synchronized Price Policies Under Inflation: The Multiproduct Monopoly Case. Review of Economic Studies, 59, 331-359.

M. E. Slade (1996a). Optimal Pricing with Costly Adjustment: Evidence from Retail-Grocery Prices. mimeo, University of British Columbia.

M. E. Slade (1996b). Sticky Prices in a Dynamic Oligopoly: An Investigation of (s, S) Thresholds. mimeo, University of British Columbia. 
D. F. Spulber (1996). Market Making by Price-Setting Firms. Review of Economic Studies, 63, No. 4, October, 559-580.

Supermarket Business (1993). Consumer Expenditures Study. September, 48, No. 9, p. 52.

D. A. Walker (1996). Walras Market Models, New York, NY: Cambridge University Press.

E. J. Warner (1995). Pricing in the Retail Industry: A Case Study. manuscript, October.

E. J. Warner and R. Barsky (1995). The Timing and Magnitude of Retail Store Markdowns: Evidence from Weekends and Holidays. Quarterly Journal of Economics, 110 , No. 2, 321-352.

O. E. Williamson (1985). The Economic Institutions of Capitalism, New York, NY: The Free Press. 
Figure 1. Overview of the Price Change Process

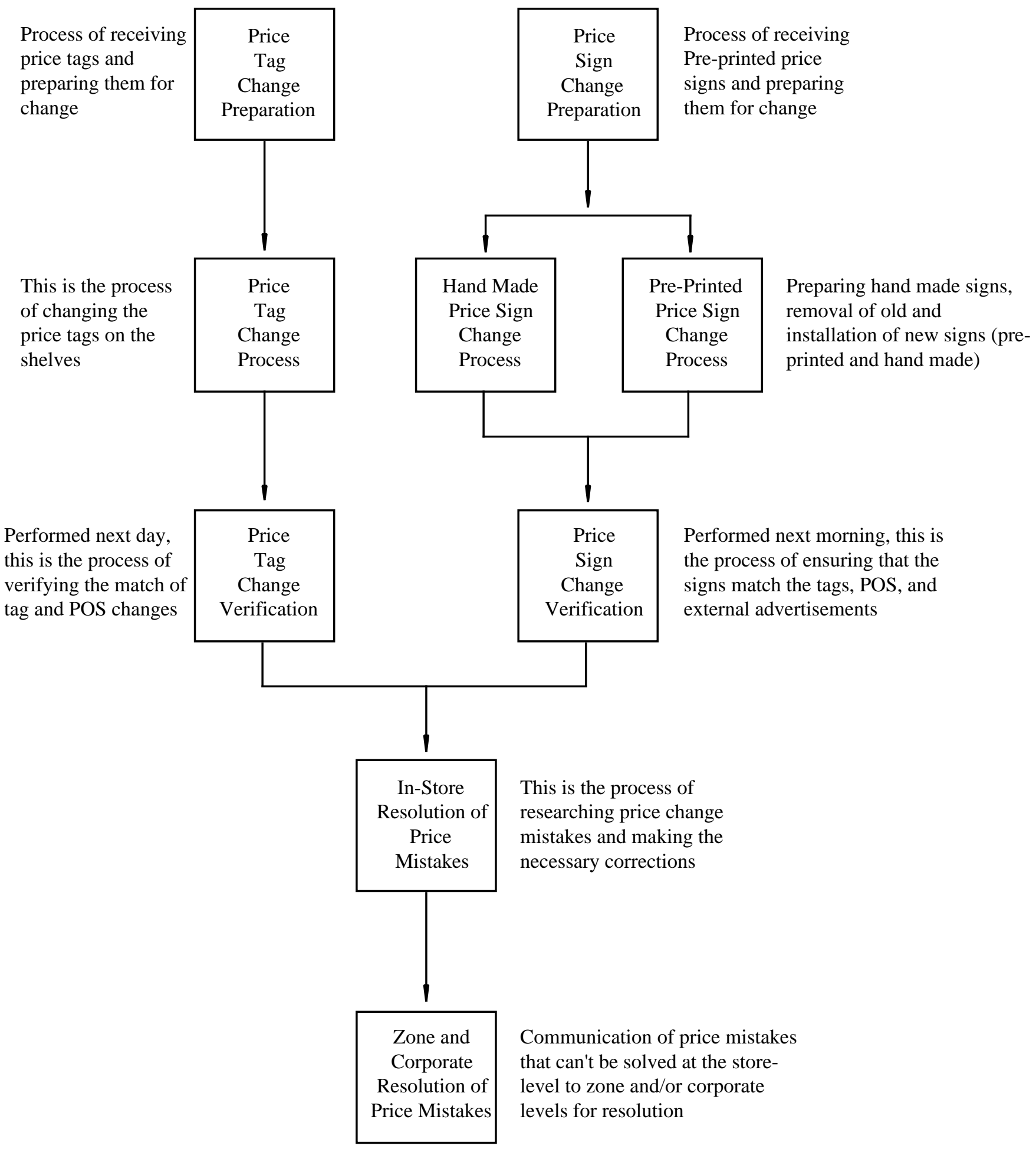

Note: POS denotes Point of Sale and refers to the cash register or the database it is connected to or both. For information on the various steps undertaken in each stage of the price change process and the amount of the labor time spent on each one of these steps, see Figures 2-11 and Tables 2-11.

Source: Levy, et al. (1997a). 
Figure 1a. Explanation of the Charting Symbols Used in Figures 2-11

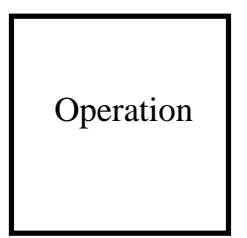

Used when something is

changed, created, added to, picked up, laid down or otherwise manipulated

within a specific work area.

Used when something is checked, compared or verified with something else. Decisions and sorting are typical uses of this symbol.

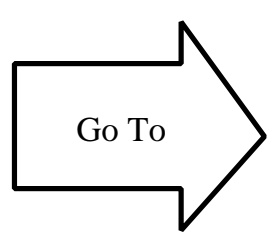

Used when something is moved from one work area to another. Also used when the person performing the task moves from one work area to another.

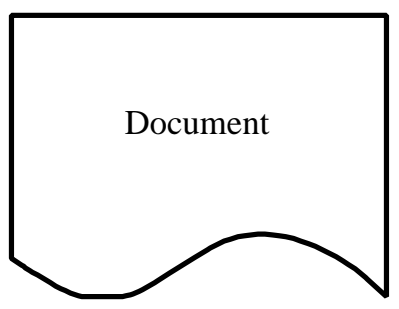

Used to depict a form or printed output.

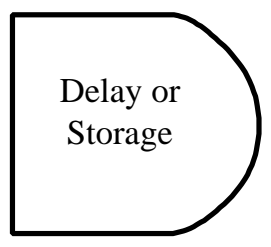

Used for unplanned, short term and controllable delays. Also for planned, longer term and uncontrollable storage.

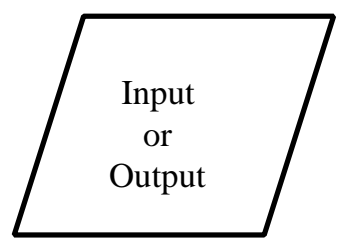

Used to indicate the use of information provided by a different flow. Display terminal or document symbols are frequently interchangable with this symbol.

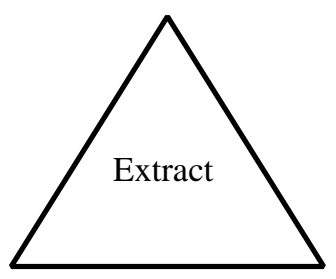

Used to indicate the process of isolating a portion of something from a larger, more varied set.

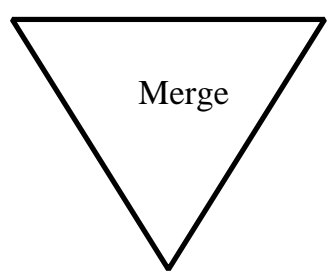

Used to combine things into a larger, more varied set.

Used to indicate a flow of information that does not require a physical movement of documents or other information storage devices.

Communications Link
Off Page Connector

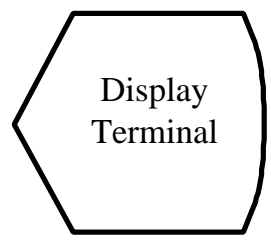

Used to indicate the entry to, or the exit from a flow defined on a different page.
Used to indicate that a display terminal is being used in the process. Usually assumes the use of a keyboard to access the information.
Key Board
Used to indicate the use of the keyboard to initiate or terminate a computer operation. Also can be used to indicate the input of data. 


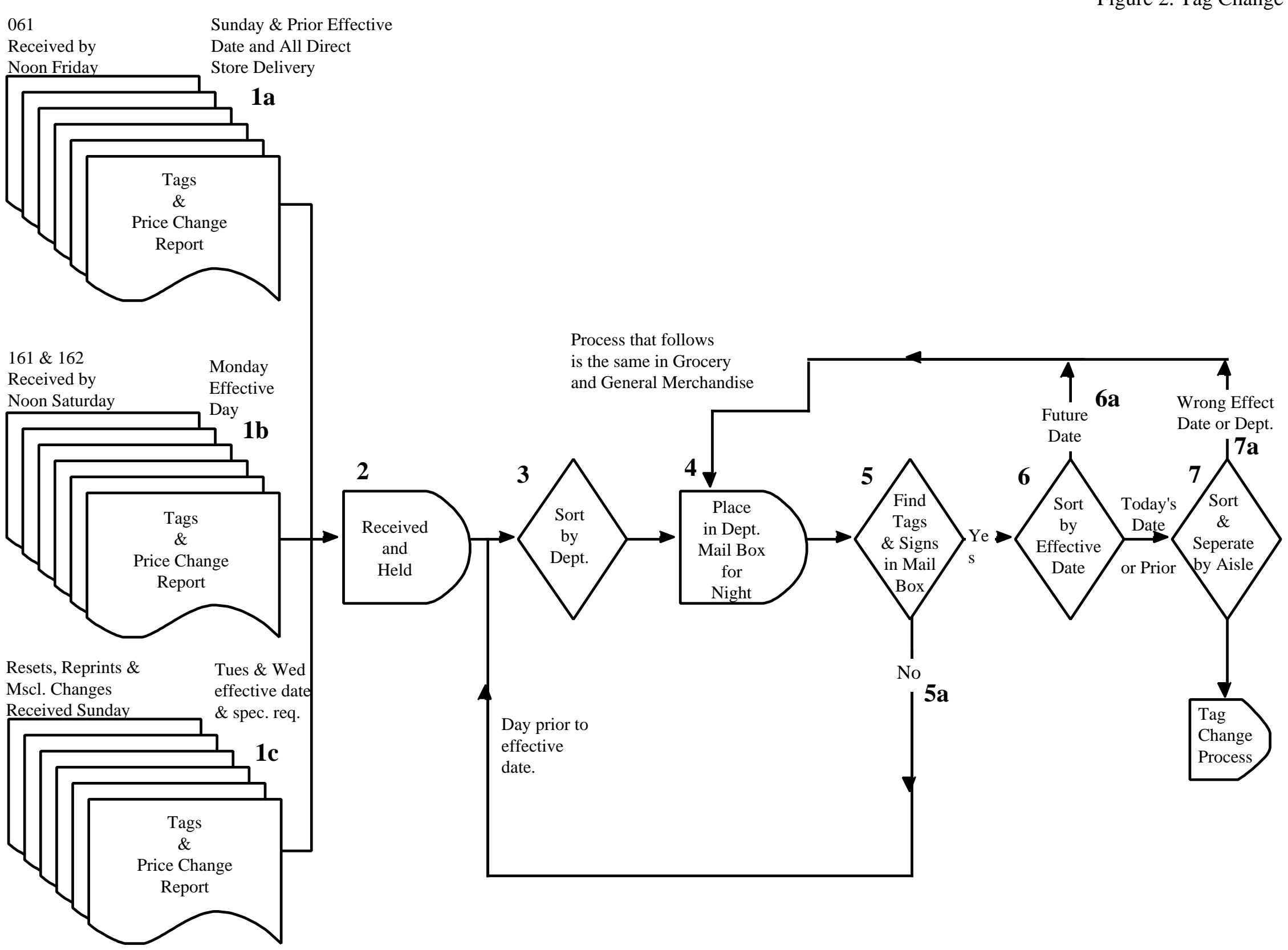


Figure 3. Tag Change Process
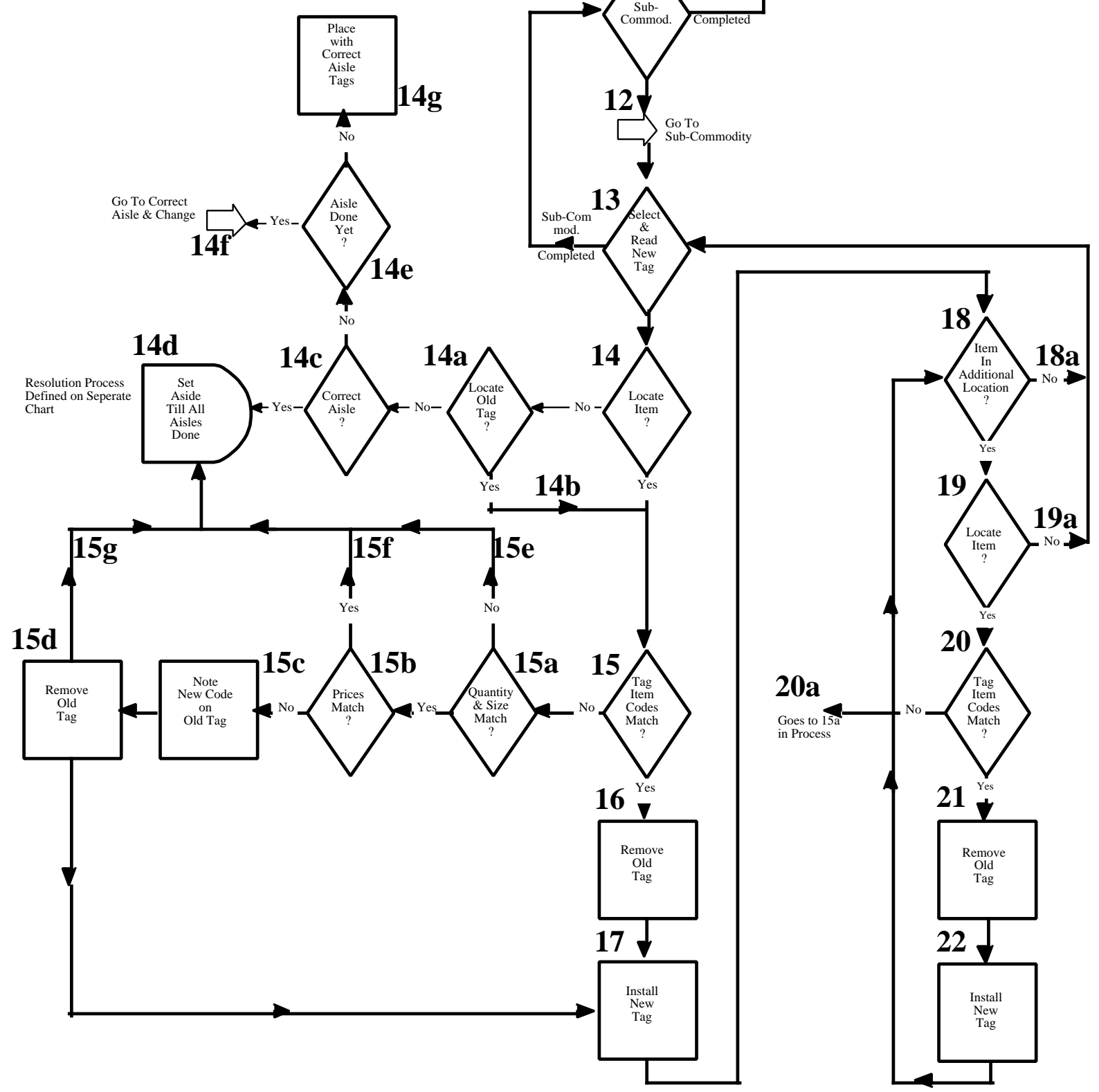
Figure 4. Tag Change Verification

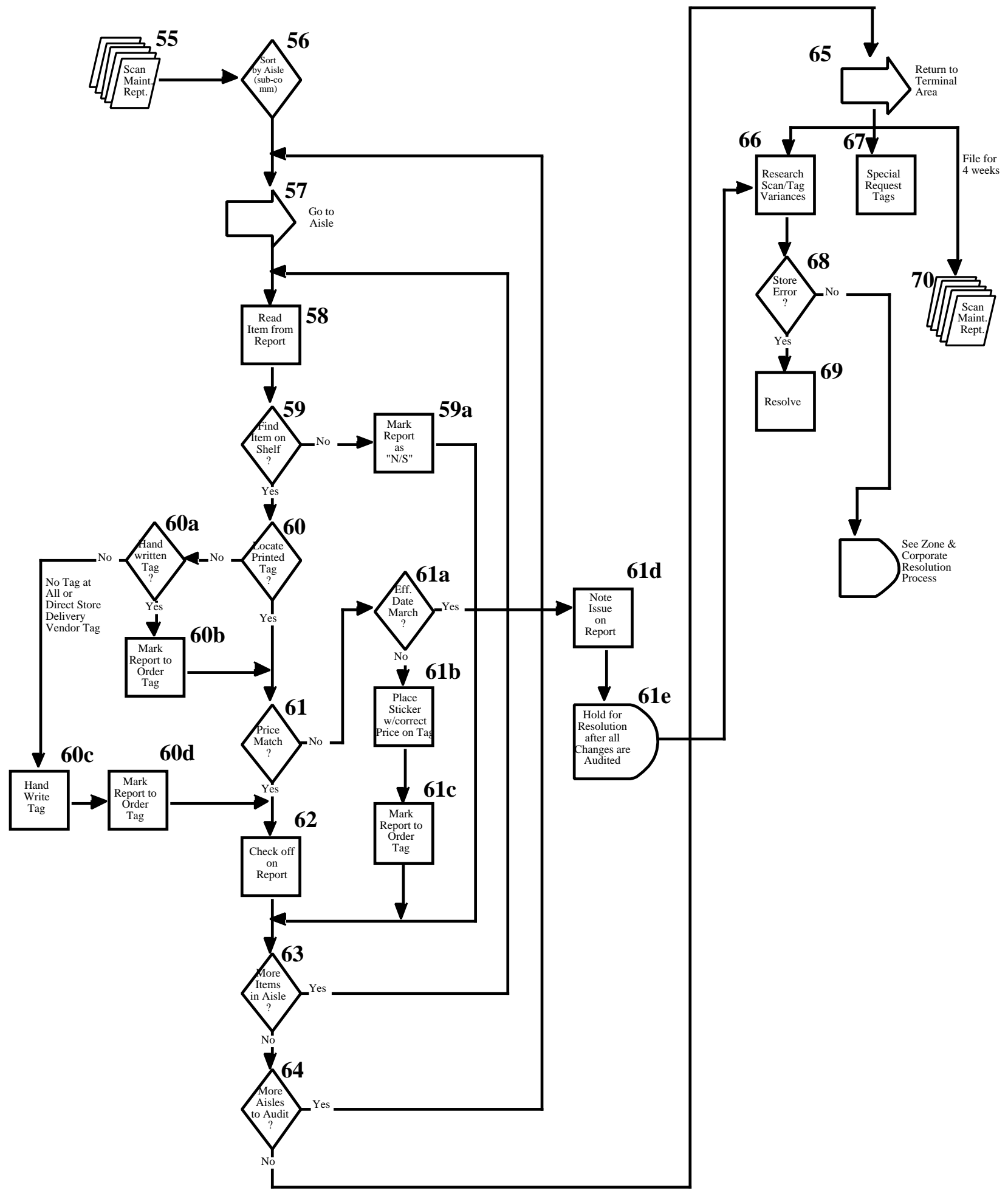


Figure 5. In-Store Resolution Process

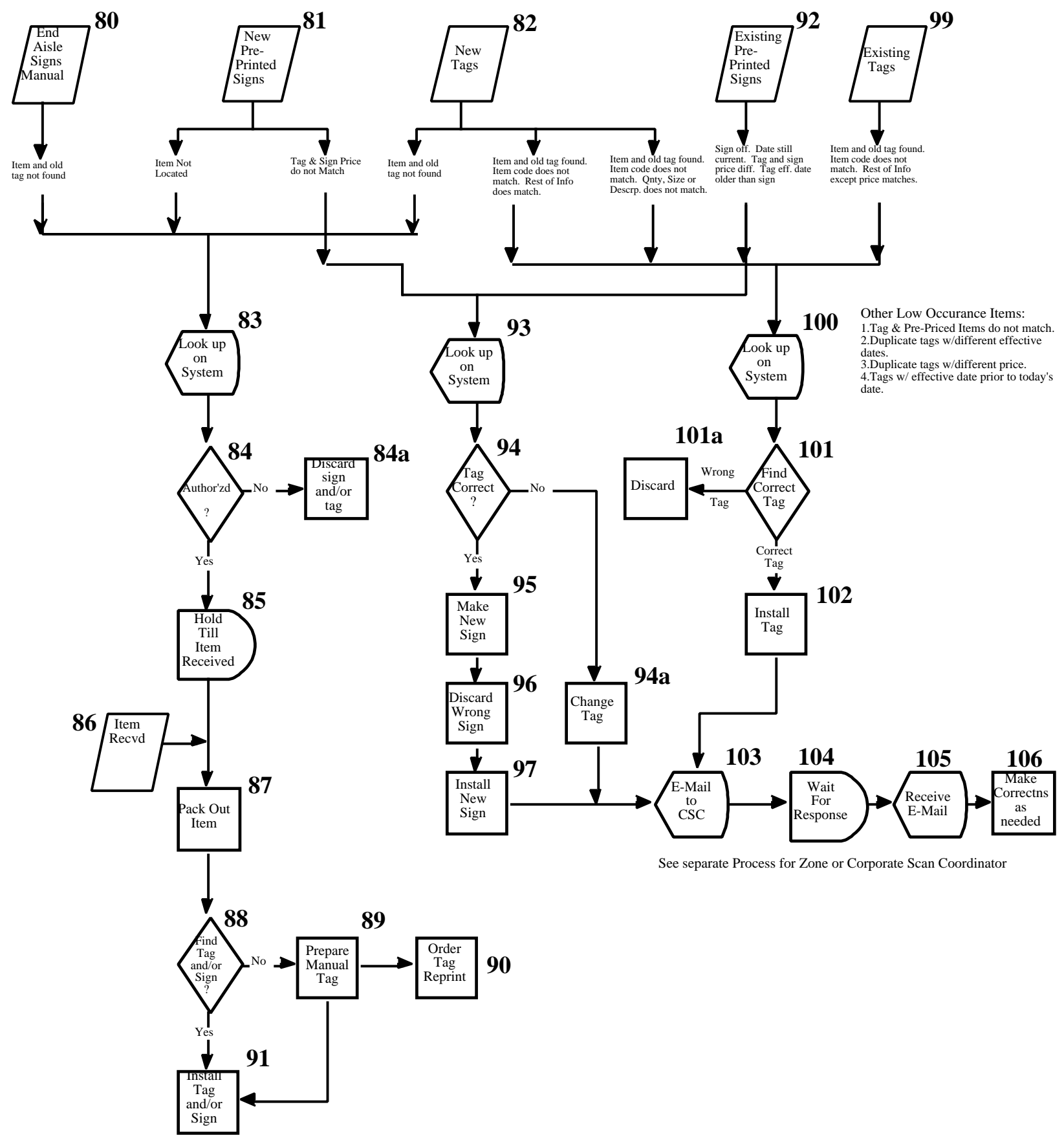


Figure 6. Zone and Corporate Resolution Process
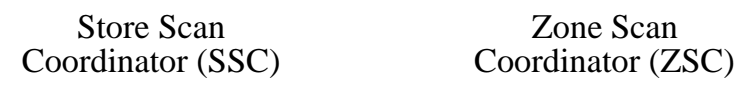

Price

Integrity
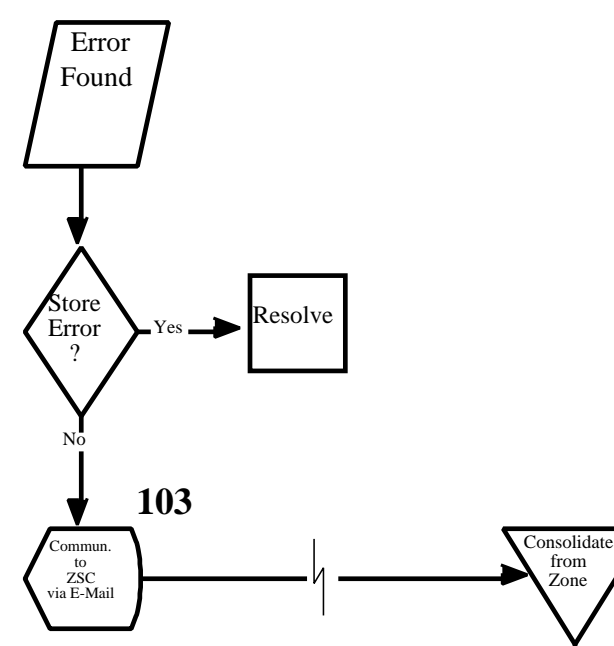

107
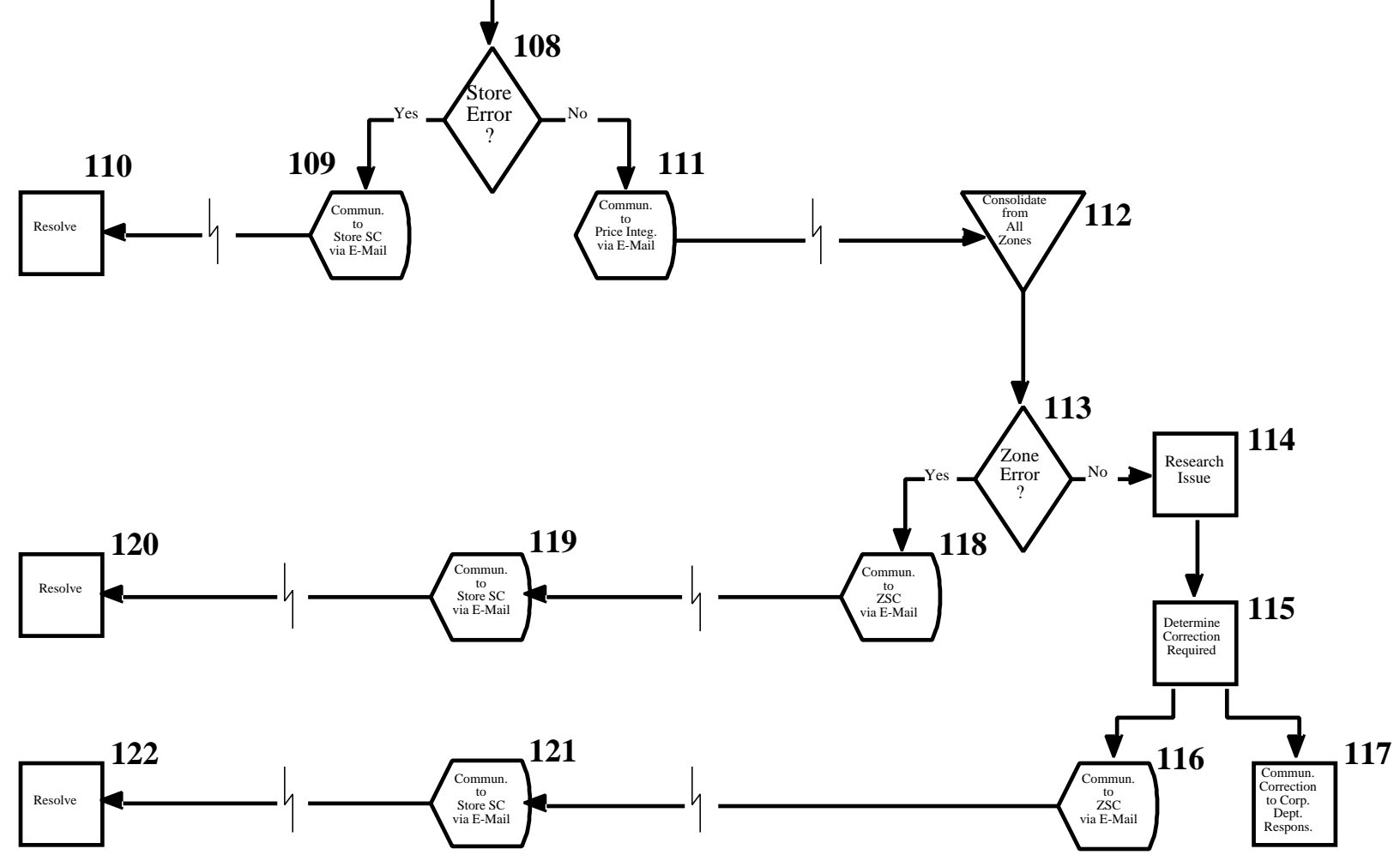

113 


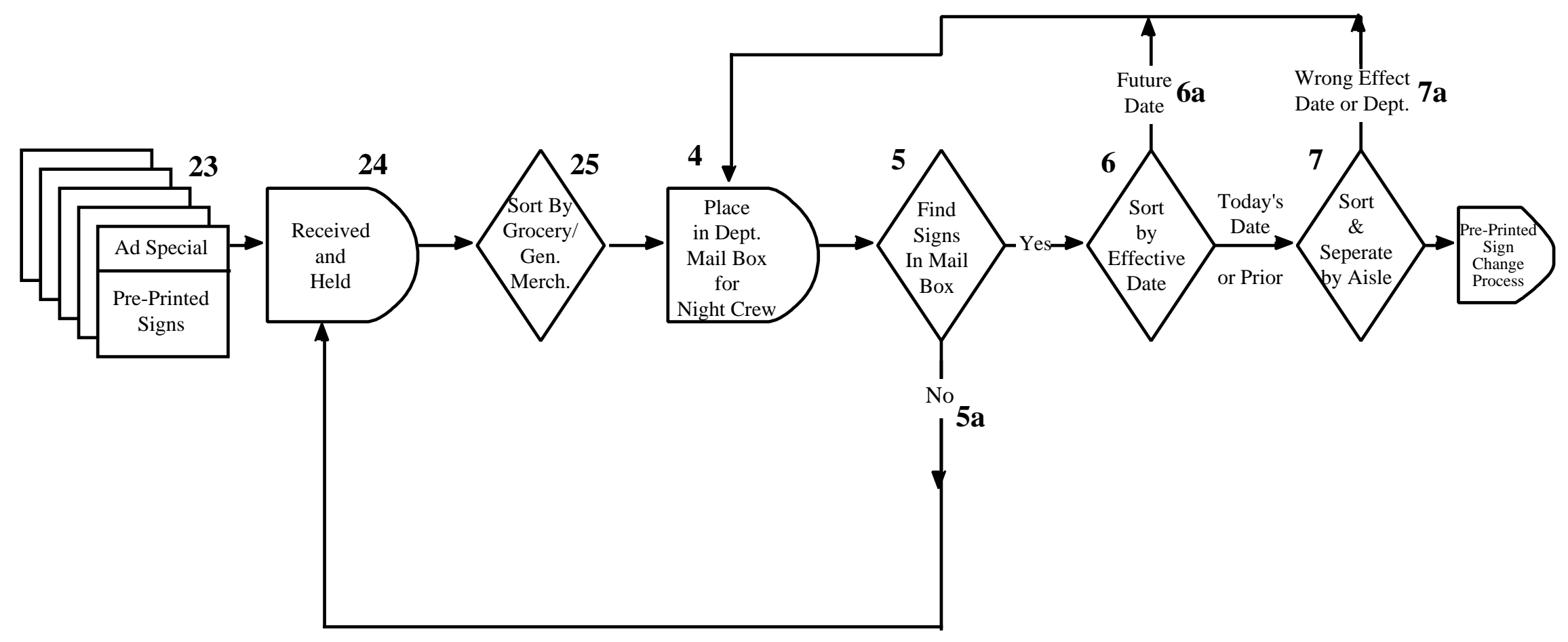


Figure 8. Hand-Made Sign Change Process

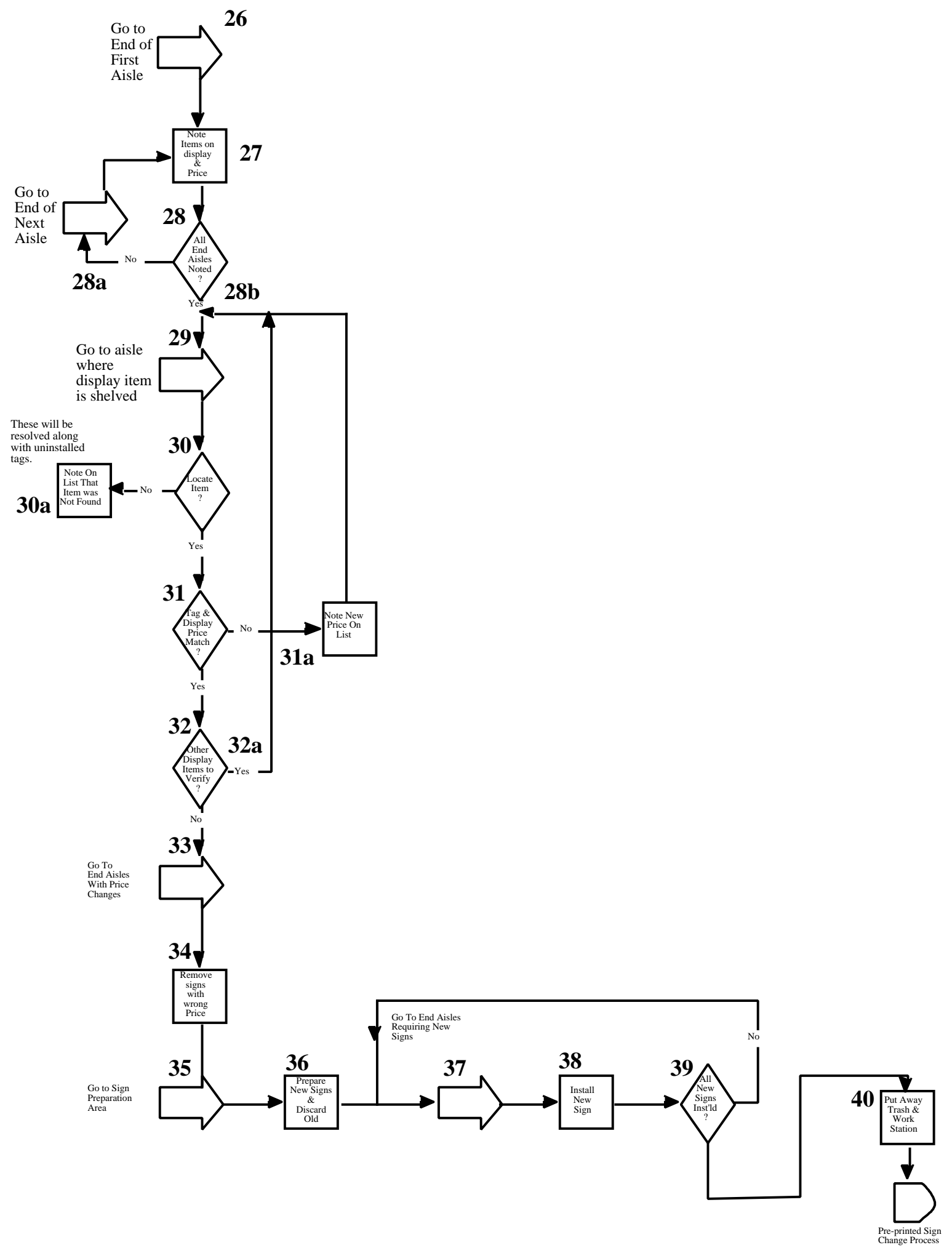


Figure 9. Pre-Printed Sign Change Process

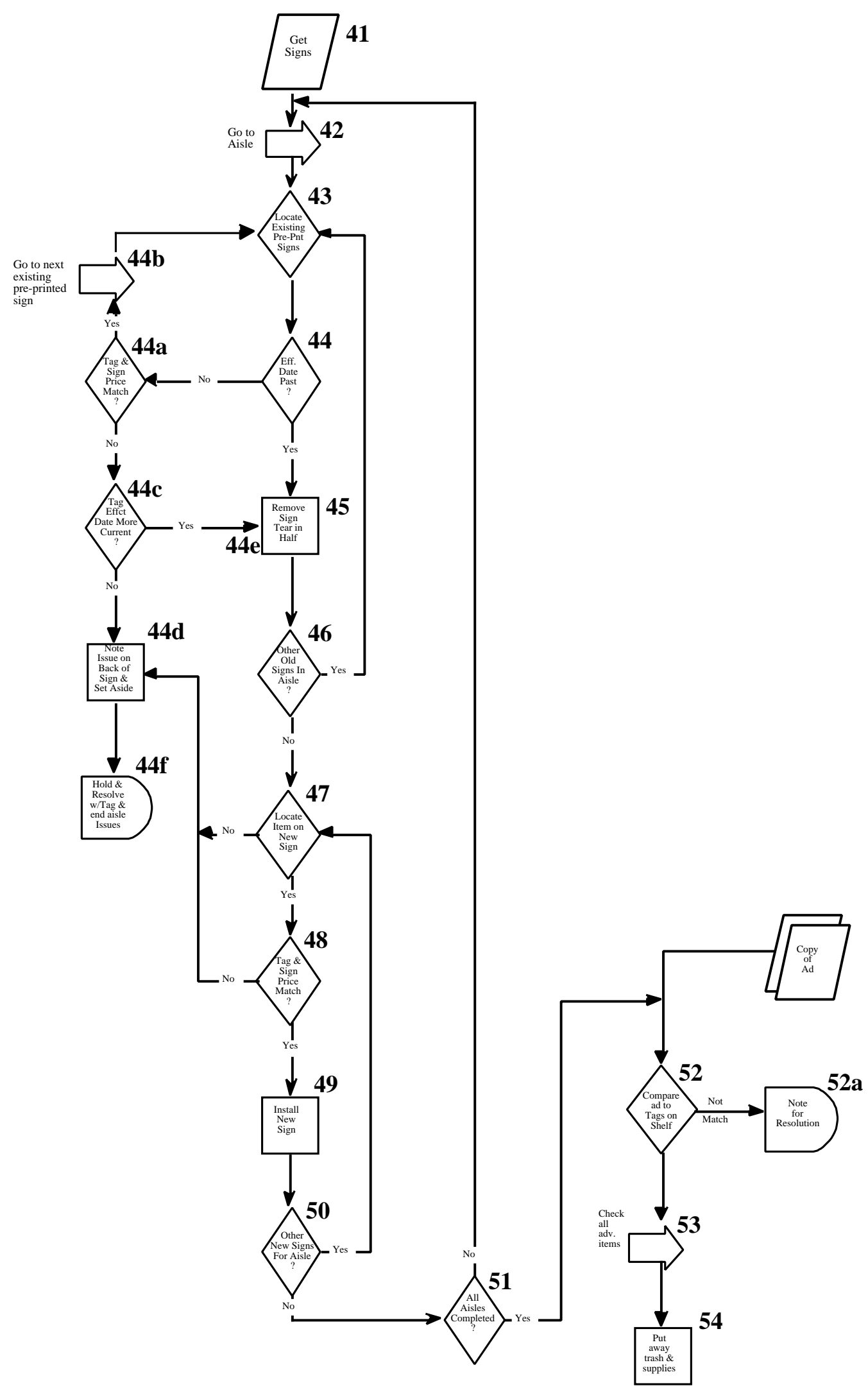


Table 1a. General Information on the Supermarket and Drugstore Chains and Their Price Change Activity

\begin{tabular}{|l|c|c|c|c|c|c|}
\hline & $\begin{array}{c}\text { Supermarket } \\
\text { Chain } \\
\text { A }\end{array}$ & $\begin{array}{c}\text { Supermarket } \\
\text { Chain } \\
\text { B }\end{array}$ & $\begin{array}{c}\text { Supermarket } \\
\text { Chain } \\
\text { C }\end{array}$ & $\begin{array}{c}\text { Supermarket } \\
\text { Chain } \\
\text { D }\end{array}$ & $\begin{array}{c}\text { Supermarket } \\
\text { Chain } \\
E^{3}\end{array}$ & $\begin{array}{c}\text { Drugstore } \\
\text { Chain }\end{array}$ \\
\hline \hline $\begin{array}{l}\text { Number of Stores } \\
\text { (Approx.) }\end{array}$ & 200 & 350 & 300 & $1,000+$ & $100-$ & $200+$ \\
\hline $\begin{array}{l}\text { Number of Products } \\
\text { Carried }\end{array}$ & 25,000 & 25,000 & 25,000 & 25,000 & 16,000 & 15,000 \\
\hline $\begin{array}{l}\text { General Pricing } \\
\text { Strategy }\end{array}$ & $\mathrm{HL}$ & $\mathrm{HL}$ & $\mathrm{EDLP}$ & $\mathrm{EDLP}$ & $\mathrm{HL}$ & 1,578 \\
\hline $\begin{array}{l}\text { No. of Price Changes } \\
\text { Per Store Per Week }\end{array}$ & 4,278 & 4,316 & 3,846 & 3,223 & 1,131 \\
\hline $\begin{array}{l}\text { Share of Products for } \\
\text { Which Prices Change in } \\
\text { an Average Week }(\%)\end{array}$ & 17.11 & 17.26 & 15.38 & 12.89 & 6.31 & 7.54 \\
\hline \hline
\end{tabular}

Notes:

1. HL (High/Low) and EDLP (Every Day Low Price) refer to the general pricing strategy followed by the retail chain. See text for details.

2. The share of products for which prices change on an average week is the ratio of number of price changes per store per week to the average number of products carried per store each week.

3. Supermarket Chain E is located in a state with Item Pricing Law which requires a price tag be posted on every single item sold by the store. This is in addition to the standard shelf price tag. See the text for more details. 
Table 1b. Within Store Distribution of Product Shares, Product Movements, and Weekly Price Changes Across Different Departments, Supermarket Chain A.

\begin{tabular}{|l|c|c|c|}
\hline Department & $\begin{array}{c}\text { Department's share in total } \\
\text { number of SKU }\end{array}$ & $\begin{array}{c}\text { Department's share of total } \\
\text { movement }\end{array}$ & $\begin{array}{c}\text { Share of average weekly price } \\
\text { changes }\end{array}$ \\
\hline \hline Grocery 1 & $34 \%$ & $58 \%$ & $34 \%$ \\
\hline Frozen Foods ${ }^{2}$ & $4 \%$ & $8 \%$ & $40 \%$ \\
\hline $\begin{array}{l}\text { General Merchandise/ } \\
\text { Health and Beauty Aid }\end{array}$ & $48 \%$ & $4 \%$ & $9 \%$ \\
\hline Dairy & $2 \%$ & $10 \%$ & $2 \%$ \\
\hline All Others & $12 \%$ & $19 \%$ & 9 \\
\hline \hline
\end{tabular}

\section{Notes:}

1. Grocery consists of regular grocery, direct store delivery grocery, grocery—small goods, and grocery docks.

2. Frozen Foods consist of frozen food, frozen meat, frozen seafood, and frozen produce.

3. General Merchandise/Health and Beauty Aids consist of direct store delivery general merchandise, skyline general merchandise and seasonals, skyline health and beauty aids, direct store delivery cosmetics, drugstore docks, and warehouse general merchandise/health and beauty aids.

4. "All Other" departments are the peripheral departments, which include bakery, floral, meat, seafood, and produce. 
Table 1c. Frequency of Price Change Activity by Product Category in Chain E: Products Subject to Item Pricing Law

\begin{tabular}{|l|c|c|c|}
\hline Product Category & Number of items & Number of price changes & Share of price changes $^{2}$ \\
\hline \hline Grocery & 8,500 & 631 & $7.4 \%$ \\
\hline Frozen Food & 1,000 & 218 & $22 \%$ \\
\hline Dairy & 500 & 147 & $30 \%$ \\
\hline Others & 15,000 & 582 & $3.8 \%$ \\
\hline Total & 25,000 & 1,578 & $6.3 \%$ \\
\hline \hline
\end{tabular}

Notes:

1. The 400 products that are exempted from the item price law requirement (see Table 1d) belong to one of the three product categories listed here.

2. The share of price changes (the last column) measures the ratio of the number of price changes to the number of items in each product category. 
Table 1d. Frequency of Price Change Activity by Product Category in Supermarket Chain E: Products Not Subject to Item Pricing Law

\begin{tabular}{|l|c|c|c|}
\hline Product Category & Number of items & Number of price changes & Share of price changes \\
\hline \hline Grocery & 256 & 43 & $17 \%$ \\
\hline Frozen Food & 117 & 26 & $22 \%$ \\
\hline Dairy & 27 & 14 & $52 \%$ \\
\hline Others & 0 & 0 & $0 \%$ \\
\hline Total & 400 & 83 & $21 \%$ \\
\hline \hline
\end{tabular}


Table 2. Tag Change Preparation

\begin{tabular}{|c|c|c|c|c|}
\hline Step & $\begin{array}{c}\text { Time/Step } \\
\text { (Seconds) }\end{array}$ & $\begin{array}{c}\text { Total Number } \\
\text { per Week }\end{array}$ & $\begin{array}{c}\text { Total Time } \\
\text { (Seconds) }\end{array}$ & $\%$ of Total \\
\hline \hline $1 \mathrm{a}$ & 0.0 & 765.8 & 0.0 & 0.00 \\
\hline $1 \mathrm{~b}$ & 0.0 & $1,762.6$ & 0.0 & 0.00 \\
\hline $1 \mathrm{c}$ & 0.0 & $1,749.7$ & 0.0 & 0.00 \\
\hline 3 & $2,124.0$ & 3.0 & $6,372.0$ & 29.39 \\
\hline 4 & 498.0 & 3.0 & $1,494.0$ & 6.89 \\
\hline 5 & 72.0 & 16.0 & $1,152.0$ & 5.31 \\
\hline $5 \mathrm{a}$ & 354.0 & 4.0 & $1,416.0$ & 6.53 \\
\hline 6 & 144.0 & 16.0 & $2,304.0$ & 10.63 \\
\hline $6 \mathrm{a}$ & 23.6 & 16.0 & 377.6 & 1.71 \\
\hline 7 & $2,124.0$ & 4.0 & $8,496.0$ & 39.18 \\
\hline $7 \mathrm{a}$ & 23.6 & 3.0 & 70.8 & 0.33 \\
\hline \hline
\end{tabular}


Table 3. Tag Change Process

\begin{tabular}{|c|c|c|c|c|}
\hline Step & $\begin{array}{c}\text { Time/Step } \\
\text { (Seconds) }\end{array}$ & $\begin{array}{c}\text { Total Number } \\
\text { per Week }\end{array}$ & $\begin{array}{c}\text { Total Time } \\
\text { (Seconds) }\end{array}$ & \% of Total \\
\hline \hline 8 & 4.8 & 42.0 & 201.6 & 0.14 \\
\hline 9 & 14.4 & 42.0 & 604.8 & 0.42 \\
\hline 10 & 1.9 & $4,278.0$ & $8,128.2$ & 5.70 \\
\hline 11 & 9.6 & 168.0 & $1,612.8$ & 1.13 \\
\hline 12 & 9.6 & 168.0 & $1,612.8$ & 1.13 \\
\hline 13 & 1.9 & 4,315 & $8,198.9$ & 5.75 \\
\hline 14 & 19.2 & 3,587 & $68,870.6$ & 48.33 \\
\hline $14 \mathrm{a}$ & 19.2 & 287.5 & 5,520 & 3.87 \\
\hline $14 \mathrm{~b}$ & 0.0 & 107.8 & 0.0 & 0.0 \\
\hline $14 \mathrm{c}$ & 2.9 & 102.4 & 297.0 & 0.21 \\
\hline $14 \mathrm{~d}$ & 1.0 & 102.4 & 102.4 & 0.07 \\
\hline $14 \mathrm{e}$ & 1.9 & 5.4 & 10.3 & 0.01 \\
\hline $14 \mathrm{f}$ & 51.4 & 2.7 & 138.8 & 0.10 \\
\hline $14 \mathrm{~g}$ & 1.9 & 2.7 & 5.1 & 0.0 \\
\hline 15 & 5.6 & $4,064.1$ & $22,759.0$ & 15.97 \\
\hline $15 \mathrm{a}$ & 4.3 & 82.1 & 353.0 & 0.28 \\
\hline $15 \mathrm{~b}$ & 3.4 & 41.0 & 139.4 & 0.10 \\
\hline $15 \mathrm{c}$ & 3.8 & 24.6 & 93.5 & 0.07 \\
\hline $15 \mathrm{~d}$ & 2.4 & 24.6 & 59.0 & 0.04 \\
\hline $15 \mathrm{e}$ & 2.9 & 41.0 & 118.9 & 0.08 \\
\hline $15 \mathrm{f}$ & 2.9 & 16.4 & 47.6 & 0.03 \\
\hline $15 \mathrm{~g}$ & 2.9 & 24.6 & 71.3 & 0.05 \\
\hline 16 & 2.4 & $3,982.1$ & $9,557.0$ & 6.71 \\
\hline 17 & 3.1 & $4,006.7$ & $12,420.8$ & 8.72 \\
\hline 18 & 0.1 & $3,593.6$ & 359.4 & 0.25 \\
\hline $18 \mathrm{a}$ & 0.0 & $3,577.6$ & 0.0 & 0.0 \\
\hline 19 & 22.0 & 35.9 & 789.8 & 0.55 \\
\hline $19 \mathrm{a}$ & 0.0 & 3.6 & 0.0 & 0.0 \\
\hline 20 & 5.6 & 38.5 & 215.6 & 0.15 \\
\hline $20 \mathrm{a}$ & 0.0 & 0.8 & 0.0 & 0.0 \\
\hline 21 & 2.4 & 37.7 & 90.5 & 0.06 \\
\hline 22 & 3.1 & 37.7 & 114.7 & 0.08 \\
\hline \hline & & Total & 142.492 .8 & 100.00 \\
\hline \hline
\end{tabular}


Table 3a. Additional Steps Undertaken During the Price Change Process in Chain E Due to the Item Price Law

\begin{tabular}{|c|c|c|c|c|}
\hline Step & Step Description & $\begin{array}{c}\text { Frequency } \\
\text { per } \\
\text { cycle }\end{array}$ & $\begin{array}{l}\text { Time per } \\
\text { cycle in } \\
\text { seconds }\end{array}$ & $\begin{array}{c}\text { Total Time } \\
\text { seconds }\end{array}$ \\
\hline 1 & Obtain labels & 0.0735 & 50.0 & 3.7 \\
\hline 2 & Set up work station & 0.0183 & 180.0 & 3.3 \\
\hline 3 & Locate the products on the shelf & 1 & 13.2 & 13.2 \\
\hline 4 & Remove an item from the shelf & 28 & 1.2 & 33.6 \\
\hline 5 & Remove old price tag & 28 & 2.2 & 61.6 \\
\hline 6 & Set price marking gun & 1 & 5.0 & 5.0 \\
\hline 7 & Apply new price tag & 28 & 1.3 & 36.4 \\
\hline 8 & Replace item on shelf & 28 & 1.7 & 47.6 \\
\hline 9 & Remove old shelf price tag & 1 & 1.0 & 1.0 \\
\hline 10 & Apply new shelf price tag & 1 & 1.5 & 1.5 \\
\hline 11 & Replace work station & 0.0183 & 180.0 & 3.3 \\
\hline $12 *$ & Customer interruptions & 0.33 & 30.0 & 9.9 \\
\hline $13 *$ & Clear jammed gun/reload gun & 0.0280 & 60.0 & 1.7 \\
\hline $14 *$ & Item packaging difficulty & 0.20 & 56.0 & 11.2 \\
\hline $15 *$ & Research price discrepancy & 0.05 & 180.0 & 1.8 \\
\hline & Total base time & & & 234.8 \\
\hline & Personal, Fatigues/Delay Allowance & & & $15 \%$ \\
\hline & Total time per product & & & 270.02 \\
\hline
\end{tabular}


Table 4. Tag Change Verification

\begin{tabular}{|c|c|c|c|c|}
\hline Step & $\begin{array}{l}\text { Time/Step } \\
\text { (Seconds) }\end{array}$ & $\begin{array}{c}\text { Total Number } \\
\text { per Week }\end{array}$ & $\begin{array}{l}\text { Total Time } \\
\text { (Seconds) }\end{array}$ & $\%$ of Total \\
\hline 55 & 0.0 & 4.0 & 0.0 & 0.0 \\
\hline 56 & 126 & 4.0 & 504.0 & 0.35 \\
\hline 57 & 21.2 & 84.0 & $1,780.8$ & 1.25 \\
\hline 58 & 4.2 & $3,593.6$ & $15,093.1$ & 10.57 \\
\hline 59 & 21.2 & $3,593.6$ & $76,184.3$ & 53.37 \\
\hline $59 a$ & 5.3 & 287.5 & $1,523.8$ & 1.07 \\
\hline 60 & 2.1 & $4,006.7$ & $8,414.1$ & 5.89 \\
\hline $60 a$ & 1.1 & 100.2 & 110.2 & 0.08 \\
\hline $60 \mathrm{~b}$ & 2.1 & 100.2 & 231.4 & 0.16 \\
\hline $60 c$ & 21.2 & 20.0 & 424.0 & 0.30 \\
\hline $60 d$ & 2.1 & 20.0 & 42.0 & 0.03 \\
\hline 61 & 5.3 & $4,006.7$ & $21,235.5$ & 14.88 \\
\hline $61 \mathrm{a}$ & 5.3 & 200.3 & $1,061.6$ & 0.74 \\
\hline $61 b$ & 15.9 & 180.3 & $2,866.8$ & 2.01 \\
\hline $61 c$ & 2.1 & 180.3 & 378.6 & 0.27 \\
\hline $61 d$ & 21.2 & 20.0 & 424.0 & 0.30 \\
\hline $61 \mathrm{e}$ & 0.0 & 20.0 & 0.0 & 0.00 \\
\hline 62 & 2.1 & $3,806.4$ & $7,993.4$ & 5.60 \\
\hline 63 & 0.0 & & 0.0 & 0.00 \\
\hline 64 & 0.0 & & 0.0 & 0.00 \\
\hline 65 & 1.1 & 4.0 & 4.4 & 0.00 \\
\hline 66 & 66.0 & 20.0 & $1,320.0$ & 0.92 \\
\hline 67 & 31.8 & 49.5 & $1,574.1$ & 1.10 \\
\hline 68 & 21.2 & 20.0 & 424.0 & 0.30 \\
\hline 69 & 47.7 & 16.0 & 763.2 & 0.53 \\
\hline 70 & 96.0 & 4.0 & 384.0 & 0.27 \\
\hline
\end{tabular}


Table 5. In-Store Resolution Process

\begin{tabular}{|c|c|c|c|c|}
\hline Step & $\begin{array}{l}\text { Time/Step } \\
\text { (Seconds) }\end{array}$ & $\begin{array}{l}\text { Total Numbers } \\
\text { per Week }\end{array}$ & $\begin{array}{l}\text { Total Time } \\
\text { (Seconds) }\end{array}$ & $\%$ of Total \\
\hline 80 & 0.0 & 1.8 & 0.0 & 0.00 \\
\hline 81 & 0.0 & 0.4 & 0.0 & 0.00 \\
\hline 82 & 0.0 & 143.4 & 0.0 & 0.00 \\
\hline 83 & 30.2 & 104.3 & $3,149.9$ & 12.03 \\
\hline 84 & 5.0 & 104.3 & 521.5 & 1.99 \\
\hline $84 a$ & 2.0 & 5.2 & 10.4 & 0.04 \\
\hline 85 & 0.0 & 99.0 & 0.0 & 0.00 \\
\hline 86 & 0.0 & 49.5 & 0.0 & 0.00 \\
\hline 87 & 0.0 & 49.5 & 0.0 & 0.00 \\
\hline 88 & 120.0 & 49.5 & $5,940.0$ & 22.69 \\
\hline 89 & 60.0 & 24.8 & $1,488.0$ & 5.68 \\
\hline 90 & 60.0 & 24.8 & $1,488.0$ & 5.68 \\
\hline 91 & 60.0 & 49.5 & $2,970.0$ & 11.34 \\
\hline 92 & 0.0 & 4.0 & 0.0 & 0.00 \\
\hline 93 & 30.2 & 4.0 & 120.8 & 0.46 \\
\hline 94 & 5.0 & 4.0 & 20.0 & 0.08 \\
\hline $94 a$ & 60.0 & 1.0 & 60.0 & 0.23 \\
\hline 95 & 180.0 & 3.0 & 540.0 & 2.06 \\
\hline 96 & 60.0 & 3.0 & 180.0 & 0.69 \\
\hline 97 & 5.0 & 1 & 15.0 & 0.06 \\
\hline 98 & 0.0 & & 0.0 & 0.00 \\
\hline 99 & 0.0 & 41.0 & 0.0 & 0.00 \\
\hline 100 & 30.2 & 41.0 & $1,238.2$ & 4.73 \\
\hline 101 & 2.0 & 41.0 & 82.0 & 0.31 \\
\hline 102 & 60.0 & 36.9 & $2,214.0$ & 8.46 \\
\hline 103 & 60.0 & 40.9 & $2,454.0$ & 9.37 \\
\hline 104 & 0.0 & & 0.0 & 0.00 \\
\hline 105 & 0.0 & & 0.0 & 0.00 \\
\hline 106 & 180.0 & 20.5 & $3,690.0$ & 14.09 \\
\hline
\end{tabular}


Table 6. Zone and Corporate Resolution Process

\begin{tabular}{|c|c|c|c|c|}
\hline Step & $\begin{array}{l}\text { Time/Step } \\
\text { (Seconds) }\end{array}$ & $\begin{array}{c}\text { Total Number } \\
\text { per Week }\end{array}$ & $\begin{array}{l}\text { Total Time } \\
\text { (Seconds) }\end{array}$ & $\%$ of Total \\
\hline 103 & 0.0 & 40.9 & 0.0 & 0.00 \\
\hline 104 & 90.0 & & 360.0 & 43.88 \\
\hline 105 & 0.0 & & 0.0 & 0.00 \\
\hline 106 & 0.0 & & 0.0 & 0.00 \\
\hline 107 & 90.0 & 1.0 & 360.0 & 43.88 \\
\hline 108 & 0.0 & 40.9 & 0.0 & 0.00 \\
\hline 109 & 3.0 & 20.5 & 61.5 & 7.50 \\
\hline 110 & 0.0 & & 0.0 & 0.00 \\
\hline 111 & 3.0 & 1.1 & 3.3 & 0.40 \\
\hline 112 & 12.0 & 0.1 & 1.2 & 0.15 \\
\hline 113 & 3.6 & 0.1 & 0.4 & 0.05 \\
\hline 114 & 48.0 & 0.0 & 0.0 & 0.00 \\
\hline 115 & 2.4 & 0.4 & 1.0 & 0.12 \\
\hline 116 & 2.4 & 0.4 & 1.0 & 0.12 \\
\hline 117 & 3.6 & 0.4 & 1.4 & 0.17 \\
\hline 118 & 7.2 & 0.1 & 0.7 & 0.09 \\
\hline 119 & 60.0 & 0.1 & 6.0 & 0.73 \\
\hline 120 & 0.0 & & 0.0 & 0.00 \\
\hline 121 & 60.0 & 0.4 & 24.0 & 2.93 \\
\hline 122 & 0.0 & & 0.0 & 0.00 \\
\hline
\end{tabular}


Table 7. Sign Change Preparation

\begin{tabular}{|c|c|c|c|c|}
\hline Step & $\begin{array}{c}\text { Time/Step } \\
\text { (Seconds) }\end{array}$ & $\begin{array}{c}\text { Total Number } \\
\text { per Week }\end{array}$ & $\begin{array}{c}\text { Total Time } \\
\text { (Seconds) }\end{array}$ & \% of Total \\
\hline \hline 23 & 0.0 & 360.0 & 0.0 & 0.00 \\
\hline 24 & 0.0 & 360.0 & 0.0 & 0.00 \\
\hline 25 & 1.9 & 360.0 & 684.0 & 48.07 \\
\hline 4 & 114.0 & 1.0 & 114.0 & 8.01 \\
\hline 5 & 58.2 & 2.0 & 116.4 & 8.18 \\
\hline $5 \mathrm{a}$ & 288.0 & 0.25 & 72.0 & 5.06 \\
\hline 6 & 58.2 & 2.0 & 116.4 & 8.18 \\
\hline $6 \mathrm{a}$ & 58.2 & 2.0 & 116.4 & 8.18 \\
\hline 7 & 9.7 & 21.0 & 203.7 & 14.32 \\
\hline $7 \mathrm{a}$ & 0.0 & 0.0 & 0.0 & 0.00 \\
\hline \hline
\end{tabular}


Table 8. Hand-Made Sign Change Process

\begin{tabular}{|c|c|c|c|c|}
\hline Step & $\begin{array}{l}\text { Time/Step } \\
\text { (Seconds) }\end{array}$ & $\begin{array}{c}\text { Total Number } \\
\text { per Week }\end{array}$ & $\begin{array}{l}\text { Total Time } \\
\text { (Seconds) }\end{array}$ & $\%$ of Total \\
\hline 26 & 55.4 & 2.0 & 221.6 & 0.29 \\
\hline 27 & 18.5 & 736.0 & $13,616.0$ & 18.11 \\
\hline 28 & 0.0 & & 0.0 & 0.00 \\
\hline $28 \mathrm{a}$ & 13.9 & 124.0 & $1,723.6$ & 2.29 \\
\hline $28 \mathrm{~b}$ & 0.0 & & 0.0 & 0.00 \\
\hline 29 & 13.9 & 736.0 & $10,230.4$ & 13.61 \\
\hline 30 & 18.5 & 736.0 & $13,616.0$ & 18.11 \\
\hline $30 \mathrm{a}$ & 4.6 & 3.6 & 16.6 & 0.02 \\
\hline 31 & 5.4 & 732.4 & $3,955.0$ & 5.26 \\
\hline $31 \mathrm{a}$ & 4.6 & 184.0 & 846.4 & 1.13 \\
\hline 32 & 0.0 & & 0.0 & 0.00 \\
\hline $32 \mathrm{a}$ & 0.0 & & 0.0 & 0.00 \\
\hline 33 & 13.9 & 31.0 & 430.9 & 0.57 \\
\hline 34 & 9.2 & 184.0 & $1,692.8$ & 2.25 \\
\hline 35 & 18.5 & 2.0 & 37.0 & 0.05 \\
\hline 36 & 108.0 & 184.0 & $19,872.0$ & 26.44 \\
\hline 37 & 13.9 & 31.0 & 430.9 & 0.57 \\
\hline 38 & 41.6 & 184.0 & $7,654.4$ & 10.18 \\
\hline 39 & 0.0 & & 0.0 & 0.00 \\
\hline 40 & 276.0 & 3.0 & 828.0 & 1.10 \\
\hline & & Total & $75,171.6$ & 99.98 \\
\hline
\end{tabular}


Table 9. Pre-Printed Sign Change Process

\begin{tabular}{|c|c|c|c|c|}
\hline Step & $\begin{array}{l}\text { Time/Step } \\
\text { (Seconds) }\end{array}$ & $\begin{array}{c}\text { Total Number } \\
\text { per Week }\end{array}$ & $\begin{array}{l}\text { Total Time } \\
\text { (Seconds) }\end{array}$ & $\%$ of Total \\
\hline 41 & 0.0 & 2.0 & 0.0 & 0.00 \\
\hline 42 & 55.5 & 2.0 & 111.0 & 0.34 \\
\hline 43 & 9.2 & 360.0 & $3,312.0$ & 10.23 \\
\hline 44 & 5.4 & 360.0 & $1,944.0$ & 6.00 \\
\hline $44 a$ & 5.4 & 36.0 & 194.4 & 0.60 \\
\hline $44 \mathrm{~b}$ & 0.0 & 28.8 & 0.0 & 0.00 \\
\hline $44 c$ & 5.4 & 7.2 & 38.9 & 0.12 \\
\hline $44 d$ & 7.4 & 0.4 & 3.0 & 0.01 \\
\hline $44 \mathrm{e}$ & 0.0 & 6.8 & 0.0 & 0.00 \\
\hline $44 \mathrm{f}$ & 0.0 & 0.4 & 0.0 & 0.00 \\
\hline 46 & 9.2 & 330.8 & $3,043.4$ & 9.40 \\
\hline 47 & 9.2 & 360.0 & $3,312.0$ & 10.23 \\
\hline 48 & 5.4 & 360.0 & $1,944.0$ & 6.00 \\
\hline 49 & 41.6 & 352.8 & $14,676.5$ & 45.32 \\
\hline 50 & 0.0 & & 0.0 & 0.00 \\
\hline 51 & 0.0 & & 0.0 & 0.00 \\
\hline 52 & 14.8 & 200.0 & $2,960.0$ & 9.14 \\
\hline $52 \mathrm{a}$ & 4.6 & 4.0 & 18.4 & 0.06 \\
\hline 53 & 0.0 & & 0.0 & 0.00 \\
\hline 54 & 276.0 & 3.0 & 828.0 & 2.56 \\
\hline & & Total & $32,385.6$ & 100.01 \\
\hline
\end{tabular}


Table 10. Sign Change Verification

\begin{tabular}{|c|c|c|c|c|}
\hline Step & $\begin{array}{c}\text { Time/Step } \\
\text { (Seconds) }\end{array}$ & $\begin{array}{c}\text { Total Number } \\
\text { per Week }\end{array}$ & $\begin{array}{c}\text { Total Time } \\
\text { (Seconds })\end{array}$ & \% of Total \\
\hline \hline 118 & 0.0 & 2.0 & 0.0 & 0.00 \\
\hline 119 & 13.9 & 62.0 & 861.8 & 5.32 \\
\hline 120 & 18.6 & 368.0 & $6,844.8$ & 42.27 \\
\hline 121 & 0.0 & 200.0 & 0.0 & 0.00 \\
\hline $121 \mathrm{a}$ & 4.7 & 200.0 & 940.0 & 5.80 \\
\hline $121 \mathrm{~b}$ & 9.3 & 10.0 & 93.0 & 0.57 \\
\hline $121 \mathrm{c}$ & 3.7 & 190.0 & 703.0 & 4.34 \\
\hline $121 \mathrm{~d}$ & 13.9 & 9.5 & 132.1 & 0.82 \\
\hline 122 & 13.9 & 21.0 & 291.9 & 1.80 \\
\hline 123 & 18.6 & 190.0 & $3,534.0$ & 21.82 \\
\hline $123 \mathrm{a}$ & 9.3 & 1.0 & 9.3 & 0.06 \\
\hline 124 & 4.6 & 189.1 & 869.9 & 5.37 \\
\hline $124 \mathrm{a}$ & 4.6 & 185.3 & 852.4 & 5.26 \\
\hline 125 & 55.7 & 3.8 & 211.7 & 1.31 \\
\hline 126 & 168.0 & 3.8 & 638.4 & 3.94 \\
\hline 127 & 55.7 & 3.8 & 211.7 & 1.31 \\
\hline \hline & & Total & $16,194.0$ & 99.99 \\
\hline \hline
\end{tabular}


Table 11. Scan Guarantee Process

\begin{tabular}{|c|c|c|c|c|}
\hline Step & $\begin{array}{c}\text { Time/Step } \\
(\text { Seconds })\end{array}$ & $\begin{array}{c}\text { Total Number } \\
\text { per Week }\end{array}$ & $\begin{array}{c}\text { Total Time } \\
(\text { Seconds })\end{array}$ & \% of Total \\
\hline \hline 128 & & & 0.0 & 0.00 \\
\hline 129 & & & 0.0 & 0.00 \\
\hline $129 \mathrm{a}$ & & & 0.0 & 0.00 \\
\hline $129 \mathrm{~b}$ & & & 0.0 & 0.00 \\
\hline $129 \mathrm{c}$ & & 126.5 & $1,568.6$ & 0.00 \\
\hline 130 & 12.4 & 126.5 & 392.2 & 4.35 \\
\hline 131 & 3.1 & 126.5 & 392.2 & 4.35 \\
\hline 132 & 3.1 & 113.9 & 706.2 & 7.84 \\
\hline $132 \mathrm{a}$ & 6.2 & 12.7 & 78.7 & 0.87 \\
\hline $132 \mathrm{~b}$ & 6.2 & 126.5 & $1,176.5$ & 13.06 \\
\hline 133 & 9.3 & 126.5 & $4,693.2$ & 52.10 \\
\hline 134 & 37.1 & Total & $9,007.6$ & 99.98 \\
\hline \hline
\end{tabular}

